Discussion Paper No. 14-120

\title{
Intangible Assets and Firm-Level Productivity
}

Dirk Crass and Bettina Peters

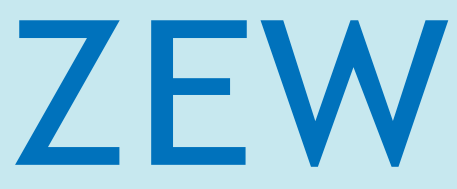

Zentrum für Europäische Wirtschaftsforschung $\mathrm{GmbH}$

Centre for European

Economic Research 
Discussion Paper No. 14-120

\title{
Intangible Assets and Firm-Level Productivity
}

\author{
Dirk Crass and Bettina Peters
}

Download this ZEW Discussion Paper from our ftp server:

http://ftp.zew.de/pub/zew-docs/dp/dp14120.pdf

Die Discussion Papers dienen einer möglichst schnellen Verbreitung von neueren Forschungsarbeiten des ZEW. Die Beiträge liegen in alleiniger Verantwortung der Autoren und stellen nicht notwendigerweise die Meinung des ZEW dar.

Discussion Papers are intended to make results of ZEW research promptly available to other economists in order to encourage discussion and suggestions for revisions. The authors are solely responsible for the contents which do not necessarily represent the opinion of the ZEW. 


\section{Non-technical summary}

It is the EU's declared objective to reap benefits from the knowledge economy. One important change that has taken place in the new initiative for smart, sustainable and inclusive growth, called Europe 2020, is the acknowledgement that knowledge capital is more than R\&D: it also includes other types of intangible capital such as design and licenses, computerized information, brand equity, firm-specific human capital, and organizational capital. Measuring such intangible assets and their impacts is a challenging task due to data limitations. It is just recently that the literature has come up with new concepts of improving the measurement of intangible assets. At the macro level, Corrado et al. (2009) provided a consistent framework for the measurement of intangible assets and simultaneously confirmed the importance of intangible capital for economic growth. They found that in the United States $11.7 \%$ of GDP was invested in intangible assets in 2003. This share is much lower in European countries, but still high. It amounted to $10.1 \%$ of GDP in the United Kingdom (Marrano and Haskel, 2007), 7.6\% in Germany (Crass et al., 2009), 8.7\% in France, $5.15 \%$ in Italy, and 5.2\% in Spain (Hao et al., 2009).

The studies mentioned above have analysed the effect of intangible assets at the national or highly aggregated industry level. Our study, in contrast, takes a micro perspective and investigates how intangible assets affect productivity at the firmlevel. It is common knowledge that there is an extremely large heterogeneity in (labour) productivity at the firm level - even within the same industry. Productivity differences seem furthermore to be a persistent phenomenon (Doms and Bartelsman, 2000). These characteristics of firm-level productivity variation and persistence has aroused research into the underlying factors (Syverson, 2011). One argument that is put forward to explain these large productivity differences is the heterogeneity of firms' investments in intangible assets, which have been insufficiently taken into account in traditional productivity estimations.

There is a substantial literature studying productivity effects of R\&D, ICT and human capital in isolation (for recent surveys see Hall et al., 2010; de la Fuente, 2011; Abramovsky and Griffith, 2009). Less is known, however, about productivity effects of other types of intangible assets. We contribute to the literature by simultaneously investigating productivity effects of a comprehensive set of intangible assets following the conceptual framework of Corrado et al. (2009) and by asking whether different kinds of intangible assets are complements or substitutes. In particular, our econometric approach accounts for Innovative Capital (measured by current R\&D expenditure, design \& licenses expenditure, and patent stock), Human Capital (proxied by training expenditure and share of high skilled labour), Branding Capital (measured by marketing expenditure and trademark stocks), and Organizational Capital (proxied by the introduction of an organizational innovation). Using panel data for German companies covering the period 2006-2010, we can draw the 
following conclusions. First, even when controlling for a comprehensive set of intangible assets, we find strong positive productivity effects for R\&D, brand capital and firm-specific human capital. However, due to collinearity the single effects turn out to be smaller compared to studies that use one type of intangible assets only. Second, we also find positive long-term productivity effects for firms investing in innovative capital and branding capital. That is both a firm's accumulated stock of granted patents and trademarks are conducive to current productivity. Our studies also show some interesting relationships between different kind of intangible assets. We find R\&D and patent stocks to be complementary, pointing to the importance of prior knowledge and the creation of absorptive capacity. Furthermore, the results show innovative capital and human capital on the one hand and innovative capital and branding capital on the other hand to be complements with respect to productivity. 


\title{
Intangible Assets and Firm-Level Productivity
}

\author{
Dirk Crass * Bettina Peters $\diamond$
}

December 2014

\begin{abstract}
Firms invest huge amounts into intangible assets. This paper explores to which extent different kinds of intangible assets are conducive to firm-level productivity. Our study contributes to the literature by simultaneously comparing productivity effects of innovative capital, human capital, branding capital and organizational capital and testing whether complementarity or substitutability exists between different intangible assets. Using panel data for the period 2006-2010, our econometric estimates confirm strong positive productivity effects of human capital and branding capital. Results for innovative capital are found to be mixed. While $\mathrm{R} \& \mathrm{D}$ has a strong positive impact on productivity, design \& licences and patents show only weak productivity enhancing effects. The same holds for organizational capital. We furthermore detect several complementarities among different kind of intangible assets. Our results are robust to various parametric (OLS, FE) and non-parametric (Olley and Pakes, Levinsohn and Petrin) productivity estimation methods.
\end{abstract}

Keywords: Intangible capital, productivity, R\&D, marketing, firm-specific human capital, organizational capital, patents, trademarks

JEL Classification: O33, C23, J24, L22

\footnotetext{
${ }^{*}$ Centre for European Economic Research (ZEW), P.O. Box 103443, 68034 Mannheim, Germany. Phone: +49 621 1235-387, Fax: +49 621 1235-170. E-mail: crass@zew.de

${ }^{\diamond}$ Centre for European Economic Research (ZEW), Mannheim Centre for Competition and Innovation (MaCCI), Zurich University, P.O. Box 103443, 68034 Mannheim, Germany. Phone: +49 621 1235-174, Fax: +49 621 1235-170. E-mail: b.peters@zew.de Acknowledgments: The authors are grateful for financial support that has been provided by the COINVEST project, www.coinvest.org.uk, funded by the European Commission Seventh Framework Programme, Theme 9, Socio-economic Science and Humanities, grant number 217512. We would like to thank Jonathan Haskel and participants at the COINVEST Conference (Lisbon, 2010), COST workshop (Amsterdam, 2010), the Comparative Analysis of Enterprise Data (CAED) conference (London, 2010), the European Association for Research in Industrial Economics (EARIE) conference (Stockholm 2011) and the workshop on "Intangibles, Innovation Policy, and Economic Growth" (Tokyo, 2012) for valuable comments. Any errors remain those of the authors.
} 


\section{Introduction}

Since the beginning of the nineties we have seen a rather weak growth performance in European countries compared to the US. The first response of the EU was the Lisbon strategy in 2000 which has recently been replaced by the new strategy for smart, sustainable and inclusive growth for high levels of employment, productivity and social cohesion, called Europe 2020. It is the EU's declared objective of this initiative to reap benefits from the knowledge economy. One important change that has taken place in the new initiative is the acknowledgement that knowledge capital is more than R\&D: it also includes other types of intangible capital such as design and licenses, computerized information, brand equity, firm-specific human capital, and organizational capital.

Measuring such intangible assets ${ }^{1}$ and their impacts is a challenging task due to data limitations. It is just recently that the literature has come up with new concepts of improving the measurement of intangible assets. At the macro level, Corrado et al. (2009) provided a consistent framework for the measurement of intangible assets and simultaneously confirmed the importance of intangible capital for economic growth. They found that in the United States $11.7 \%$ of GDP was invested in intangible assets in 2003. This share is much lower in European countries, but still high. It amounted to 10.1\% of GDP in the United Kingdom (Marrano and Haskel, 2007), 7.6\% in Germany (Crass et al., 2009), 8.7\% in France, 5.15\% in Italy, and 5.2\% in Spain (Hao et al., 2009). Using a growth accounting framework, Corrado et al. (2009) also showed that intangible investment stimulated labour productivity growth in the United States by 0.84 percentage points. The growth enhancing effect is smaller in many European countries but still considerable: Labour productivity was boosted by 0.58 percentage points in the UK, 0.53 in Germany, 0.34 in Italy, and 0.19 in Spain.

The studies mentioned above have analysed the effect of intangible assets at the national or highly aggregated industry level. Our study, in contrast, takes a micro perspective and investigates how intangible assets affect productivity at the firmlevel. It is common knowledge that there is an extremely large heterogeneity in (labour) productivity at the firm level - even within the same industry. Productivity differences seem furthermore to be a persistent phenomenon (Doms and Bartelsman, 2000). These characteristics of firm-level productivity variation and persistence has aroused research into the underlying factors (Syverson, 2011). One argument that is put forward to explain these large productivity differences is the heterogeneity of firms' investments in intangible assets, which have been insufficiently taken into account in traditional productivity estimations.

There is a substantial literature studying productivity effects of R\&D, ICT and human capital in isolation (for recent surveys see Hall et al., 2010; de la Fuente, 2011;

\footnotetext{
${ }^{1}$ We use the terms intangible assets and intangible capital interchangeably.
} 
Abramovsky and Griffith, 2009). Less is known, however, about productivity effects of other types of intangible assets. We contribute to this strand of literature in two ways. First we simultaneously account for different types of intangibles in the spirit of Corrado et al. (2009). In addition to R\&D and human capital, we examine how and to what extent other intangible capital input factors like investments in design and licenses, brand capital and organizational capital can explain the variability of firm productivity. By simultaneously accounting for different types of intangibles we are better able to identify and isolate productivity effects of each category. Second, we provide evidence on whether complementarity or substitutability exists between investments in different kinds of intangible assets. In order to detect complementary or substitutive relationships we follow a recent test approach proposed by Carree et al. (2011). The empirical analysis is based on the Mannheim Innovation Panel (MIP), the German contribution to the European-wide Community Innovation Surveys (CIS). As a distinctive feature MIP provides information on expenditures related to intangible assets for German companies from the period 2006 to 2010 .

The outline of this paper is as follows. Section 2 summarises the main empirical firm-level evidence on productivity effects of intangibles that is beyond the consideration of $\mathrm{R} \& \mathrm{D}$. Our econometric framework is presented in section 3. The data set and variables are described in section 4. Stylized facts about the investments in intangible assets and productivity differences are presented in section 5. Results of the econometric analysis are given in section 6 . The last section 7 draws some conclusions and discusses the main findings.

\section{Productivity Effects of Intangible Assets}

Many firms spend a large amount on intangible assets such as R\&D, design, branding, organizational or human capital. As already pointed out, a major challenge in quantifying the productivity effects of such intangible assets roots in the problem of measuring them appropriately. Data for some of these components, like scientific $\mathrm{R} \& \mathrm{D}$, are well documented, internationally harmonized and comparable to a large extent. Other categories like organizational capital, however, are rather crudely measured so far. In addition, accounting rules for these components differ across accounting standards. Depending on the type of intangible asset, ${ }^{2}$ they have to be capitalized if they fulfil certain criteria (e.g. development expenditures in IAS), firms can opt for capitalization (e.g. own produced fixed intangible assets in German accounting standard HGB) or they are not allowed to be capitalized and treated as expenses (e.g. research expenditures in IAS and HGB, own produced trademarks or

\footnotetext{
${ }^{2}$ The international accounting standard IAS defines an intangible asset as an "identifiable nonmonetary asset without physical substance".
} 
goodwill in HGB).

In a recent study, (Marrocu et al., 2012) examine the impact of intangible capital on firms' productivity level in six European countries: France, Italy, Netherlands, Spain, Sweden and the United Kingdom. Their study relies on balance sheet information for the period 2002 to 2006 and thus intangible capital comprises only those intangible assets that have been capitalized. Based on a Cobb-Douglas production function approach they find a highly significant effect of intangible capital on productivity. The impact of intangible capital, however, turns out to be lower than that of physical capital. The estimated elasticity of about $0.04-0.06$ is only roughly half as large as that of physical capital. Moreover, they corroborate a productivityenhancing effect in all countries. The variation across countries turns out to be relatively large. The impact is more than three times larger in the UK (0.09) than in Spain (0.023).

The study by Bontempi and Mairesse (2014) goes beyond the impact of purely capitalized intangible assets. In comparing productivity effects of intangible relative to tangible capital, they differentiate between capitalized versus expensed intangible capital on the one hand and intellectual (mainly R\&D and patents) versus customer intangible capital (mainly advertising, trademarks) on the other hand. Using data for Italian firms, their estimates also provide evidence that intangible capital has a stimulating effect on productivity. They find a strong positive relationship between intangible capital and productivity levels with an estimated output elasticity of about 0.025 whereas the nexus was much weaker in terms of productivity growth (estimated output elasticity of 0.012). In contrast to Marrocu et al. (2012) their results further show that intangible capital and its different components are at least as productive as tangible capital. Focussing on intangible components, they find that intangible capital based on current expenses which involves a higher risk is less productivity-enhancing than capitalized intangible capital.

Both studies investigate the effect of intangible capital as a whole or in broad categories (intellectual versus consumer-related) without disentangling the effect of single intangible components. The most prominent component that has deserved a lot of attention in the literature is $\mathrm{R} \& \mathrm{D}$. At the micro level, the productivity-enhancing effect of R\&D is well documented. Starting with the seminal work by Griliches (1979), many studies have investigated the impact of R\&D on productivity at the firm level. We refer to the recent survey by Hall et al. (2010) and the references cited therein. In a nutshell, they conclude that most studies show a significant positive private return to $\mathrm{R} \& \mathrm{D}$, ranging mostly between 20 to $30 \%$. The corresponding output elasticity of $R \& D$ ranges from 0.01 to 0.25 in most studies and is often centered around 0.08 .

Greenhalgh and Longland (2005) measure productivity effects of innovative capital through a set of indicators: In addition to R\&D expenditures they use patents and 
trademark registrations. They find for their sample of manufacturing firms that trademark activity is correlated with permanent productivity gains. Greenhalgh and Rogers (2012) also examine the role of trademark activity on productivity. Firms which apply for a trademark in the previous year are defined as trademark active. They find trademark activity leads to significantly higher productivity and improved productivity growth. Trademarking firms have between $10 \%$ and $30 \%$ significantly higher value added than non-trade markers.

Other components of intangible capital have attracted much less attention, again mainly because of difficulties in measurement. In the terminology of Corrado et al. (2009) one of these components is computerized information. At the firm-level, an increasing number of studies have investigated the effect of information technology (computer hardware and peripherals), communication technology (mainly broadband) or ICT in general on productivity. Recently, Software has been considered also (Sarbu, 2013). These studies provide empirical evidence of a positive and significant productivity effect of ICT in general (Bertschek and Kaiser, 2004; Hempell, 2005), IT (Brynjolfsson and Hitt, 1996; Bresnahan, 2002) and broadband (Grimes et al., 2012). The estimated output elasticity of ICT is in the 0.05 range (see Kretschmer et al., 2013) and has increased over time. This contradicts the Solow paradox, which stated that computers are everywhere but in the productivity statistics (Solow, 1987). See for instance the surveys by Kretschmer et al. (2013); Brynjolfsson and Hitt (2003); Bertschek (2003), or Draca et al. (2007). Brynjolfsson and Hitt (2003) found for example that over short horizons, estimated output contributions of computers are roughly equal to their costs. Over longer time horizons computerization is associated with an output contribution between two and five times as much as the short-run impact. Moreover, they emphasize that relatively large and time-consuming investments in complementary inputs, such as organizational capital, are required. Polder et al. (2009) extended the standard CDM framework that relates innovation input to innovation output and innovation output to productivity (see also Crépon et al., 1998). They include investment in ICT as an endogenous input into innovation output and analyse the combined implementation of product, process and/or organizational innovation on productivity. Data on organizational innovation are sourced from the Community Innovation Survey (CIS) for the Netherlands. Organizational innovation includes the introduction of new business practices, knowledge management systems, methods of workplace organization, and management of external relations. The introduction of an organizational innovation can be seen as a change in the organizational capital of a firm. Their findings indicate that in manufacturing the strongest productivity effects have been derived from organizational innovation. In services, the strongest productivity effect results from the combined use of process and organizational innovation. Furthermore, they show that organizational and product innovations are substitutes 
whereas organizational innovation and process innovation are complements. In a recent series of studies, Bloom, Sadun and Van Reenen have investigated the effect of various organizational and management practices on productivity (Bloom and van Reenen, 2007; Bloom et al., 2010, 2012). Bloom and van Reenen (2007) conducted a telephone survey of 732 medium-sized manufacturing firms in the United States, the United Kingdom, France, and Germany. Based on a five-point Likert scale of 18 practices which are grouped into the areas operations, monitoring, targets, and incentives, they derive a measure of overall managerial practice. They find better managerial practice to be strongly associated with higher firm-level productivity.

Another important component of intangible capital is firm-specific human capital, measured by training expenditures in the Framework of Corrado et al. (2009). The impact of training on firm productivity has been investigated by a relatively small number of empirical papers, with special attention being paid to the relationship of human capital and wages. The background for this is the (simplest) neoclassical view of a perfect competitive labour market where wages will be equal to the value of the marginal product of labour. Thus, wages can be used a direct measure of productivity. However, empirical studies listed below suggest that the productivity effect of training is higher than the wage effect and thus wages as direct productivity measures may underestimate the role of training. In our context it is important to note that a positive correlation of training and productivity is generally found. One example is the sector-level study of Dearden et al. (2006). They use a panel of British industries and confirm (based on a Cobb-Douglas production function) a statistically and economically significant impact of work-related training on productivity in the private sector: A one percent increase in training is associated with an increase in value added per hour of about 0.6 percent. Black and Lynch (1996) study the relationship of human capital investments in the form of employer provided training on business productivity. Using survey data on U.S. establishments with more than 20 employees they estimate a Cobb-Douglas production function and find that the number of workers trained has no significant impact on productivity. However, the greater the proportion of time spent in formal off-the-job training, the higher the productivity in manufacturing firms. Black and Lynch (2001) find mixed evidence: raising the average educational level of workers increase productivity while training has no impact. Konings and Vanormelingen (2009) examined the effect of training on productivity and wages. They make use of firm-level panel data on various elements of training from annual reports of Belgian firms to simultaneously estimate a wage equation and a production function. They estimate a productivity premium for a trained worker of 23 percent and a wage premium of training that is roughly 12 percent. Thus, training enhances marginal productivity more than it increases the wage of the respective employee. Furthermore, they found that training has a slightly higher impact in services compared to manufacturing. 
But so far only a very few papers have investigated the effect of different intangible components at the same time. Ballot et al. (2006) examined the effect of training and R\&D on productivity using firm-level data for France and Sweden. They found the effect of training to be larger than that of $R \& D$. The estimated average output (value added per employee) elasticity of training and R\&D amounts to 17.3 and 5.4 percent in France and 7.3 and 6.1 percent in Sweden, respectively. In addition, they corroborate a significant positive complementarity effect between training and $\mathrm{R} \& \mathrm{D}$. That is, the empirical results indicate that training (R\&D) has a larger positive impact on productivity if the firm has accumulated a higher stock of R\&D capital (human capital). In a recent study, Ramirez and Hachiya (2008) measured the contribution of intangibles to productivity growth of Japanese firms. They distinguish $R \& D$, advertising and firm-specific organizational capital. A special feature of their study is that firm-specific organizational capital growth is not directly measured but approximated by the estimated fixed effect of an annual growth equation. They conclude that firm-specific organizational capital is one of the most critical factors in determining the productivity growth and advertising is one of the most productive inputs.

Our study contributes to the literature by simultaneously investigating the productivity effects of a comprehensive set of intangible components similar to the ones proposed by Corrado et al. (2009). By simultaneously accounting for different types of intangibles, we are better able to identify and isolate productivity effects of each category. As explained in more detail in section 4, we include different measures for Innovative Capital, Human Capital, Branding Capital, as well as Organizational Capital. Furthermore, we investigate whether complementarity or substitutability exists between investments in different kinds of intangible assets.

\section{Econometric Framework}

Most of the studies mentioned above have used a production function approach in general and a Cobb-Douglas production function in particular as their theoretical framework (see, for example, Mairesse and Sassenou, 1991). We follow this line of research and estimate in the first stage firm level Total Factor Productivity (TFP) and in the second stage the contribution of several intangible assets on TFP.

\section{First stage: Estimation of TFP}

The output of firm $i$ at time $t$ can be described by the Cobb-Douglas production function:

$$
Q_{i t}=A_{i t} L_{i t}^{\beta_{l}} K_{i t}^{\beta_{k}} M_{i t}^{\beta_{m}}
$$


where $Q_{i t}, M_{i t}$, and $K_{i t}$ denote firm $i^{\prime} s$ value of output, material, and physical capital and $L_{i t}$ denotes its labour input, measured as the number of employees. $A_{i t}$ is a measure of firm $i^{\prime} s$ level of efficiency, commonly referred to as Total Factor Productivity (TFP). The effect of $A_{i t}$ on $Q_{i t}$ is assumed to be Hicks-neutral, so TFP is additively separable from the other production factors. ${ }^{3}$

An alternative representation of equation (1), where small letters denote corresponding log values, constitutes a linear production function,

$$
q_{i t}=\beta_{0}+\beta_{l} l_{i t}+\beta_{k} k_{i t}+\beta_{m} m_{i t}+\omega_{i t}+\eta_{i t}
$$

where $\ln \left(A_{i t}\right)$ is now decomposed into three elements, $\beta_{0}, \omega_{i t}$, and $\eta_{i t}$. The first element, $\beta_{0}$, represents mean efficiency across all firms and $\omega_{i t}$ denotes the time- and firm-specific deviation from that mean, while $\eta_{i t}$ is a true error term that contains unobserved shocks and measurement errors. We assume that the firm-specific deviation from the mean efficiency is observable by the firm when it makes its investment decision, but not by the econometrician.

Since we are interested in analysing the influence of intangibles on productivity, we define the left hand side as output per employee and therefore as labour productivity:

$$
q_{i t}-l_{i t}=\beta_{0}+\left(\beta_{l}-1\right) l_{i t}+\beta_{k} k_{i t}+\beta_{m} m_{i t}+\omega_{i t}+\eta_{i t}
$$

With a little algebra, equation (3) becomes:

$$
q_{i t}-l_{i t}=\beta_{0}+\left(\beta_{l}+\beta_{k}+\beta_{m}-1\right) l_{i t}+\beta_{k}\left(k_{i t}-l_{i t}\right)+\beta_{m}\left(m_{i t}-l_{i t}\right)+\omega_{i t}+\eta_{i t}
$$

Equation (4) allows us to test for constant returns to scale. A labour coefficient significantly greater (smaller) than zero, suggests increasing (decreasing) returns to scale. In the case of constant returns to scale in all input factors, i.e. $\mu=$ $\beta_{l}+\beta_{k}+\beta_{m}=1$, the production function becomes:

$$
q_{i t}-l_{i t}=\beta_{0}+\beta_{k}\left(k_{i t}-l_{i t}\right)+\beta_{m}\left(m_{i t}-l_{i t}\right)+\omega_{i t}+\eta_{i t}
$$

Based on the estimates of equation (4), which will be explaned in more detail in section 6 , total factor productivity is computed in the following way,

$$
\widehat{T F P}_{i t}=\left(q_{i t}-l_{i t}\right)-(\widehat{\mu}-1) l_{i t}-\widehat{\beta}_{k}\left(k_{i t}-l_{i t}\right)-\widehat{\beta_{m}}\left(m_{i t}-l_{i t}\right)
$$

\footnotetext{
${ }^{3}$ For recent efforts of allowing for labour-augmenting biased technological change see Doraszelski and Jaumandreu (2014)
} 


\section{Second stage: The contribution of intangible assets to TFP}

The estimate for Total Factor Productivity $\widehat{T F P}_{i t}$ resulting from equation (6) is used in the second stage to evaluate the impact of intangible assets. The resulting regression looks as follows:

$$
\widehat{T F P}_{i t}=\gamma_{1} I C_{i t}+\gamma_{2} H C_{i t}+\gamma_{3} B C_{i t}+\gamma_{4} O C_{i t}+X_{i t}+\varepsilon_{i t}
$$

where IC denotes Innovative Capital, HC captures Human Capital, BC is Branding or Reputation Capital and OC stands for Organizational Capital. In addition to intangible capital, a set of control variables $X_{i t}$ is included. In the following section, we describe the data set and the measurement of the variables used in the econometric analysis.

\section{Data and Variables}

\subsection{Data}

Our study makes use of the Mannheim Innovation Panel (MIP). The MIP is the official German innovation survey. Since 1993 the survey has been conducted annually by the Centre for European Economic Research (ZEW), infas-Institut für Sozialforschung and ISI Fraunhofer Institute on behalf of the German Federal Ministry of Education and Research. Initially every fourth year and since 2005 every second year it is the German contribution to the European Community Innovation Survey (CIS), co-ordinated by Eurostat. The methodology and questionnaires are internationally harmonized across the countries. The survey is representative for all enterprises with at least five employees in German manufacturing and services. The sample is drawn as a stratified random sample, using industry (Nace 2-digit classification), firm size (eight size classes: 5-9, 10-19, 20-49, 50-99, 100-249, 250499, 500-999, 1000 and more) and region (East and West Germany) as stratification criteria. The survey is voluntary in Germany and each year between 5000 and 7000 enterprises in manufacturing and services respond to the survey and provide information on their innovation activities and some general firm characteristics such as sales, employment, exports, physical capital or investment. Primary respondents are general managers and heads of $\mathrm{R} \& \mathrm{D}$ departments or innovation management department. ${ }^{4}$ For a more detailed description of the dataset and the survey see Peters (2008), Aschhoff et al. (2013) and Peters and Rammer (2013). Since not all categories of intangible capital were asked for the whole period, we have to restrict the empirical analysis to the surveys 2007-2011 which cover the time period 20062010. All variables expressed in Euro values are deflated by industry-specific price

\footnotetext{
${ }^{4} 76 \%$ of the questionnaires are filled out by general managers and CEOs, $3 \%$ by head of R\&D departments. Another $14 \%$ of respondents belong to controlling and accounting.
} 
indices published by the German statistical office. Our unbalanced panel consists of 6,231 firms with an average participation of 1.77 and 11,021 observations in total.

\subsection{Variables}

\subsubsection{Dependent Variable}

Since our panel is rather short and unbalanced, we use TFP in levels instead of TFP growth as our main dependent variable. As a robustness check, we furthermore study the impact of intangibles on labour productivity, which is defined as the logarithm of sales per employee.

\subsubsection{Traditional Factor Inputs}

The productivity equation controls for input variations in material and physical capital. Capital measures physical capital which is defined as tangible assets in book value per employee in year $\mathrm{t}$ (in log.). Information on tangible assets is directly inquired in the survey. Material is defined as material costs per employee in year $\mathrm{t}$ (in log.). Material costs actually comprise expenditures for materials, intermediate inputs and energy (including ordered services). Both Capital and Material as well as the amount of investment in physical capital (Investment) are direct information from the MIP. Although productivity is measured in intensity form, Labour is additionally included in the set of explanatory variables. This specification allows us to test for the hypothesis of constant returns to scale which corresponds to a zero coefficient of Labour. Labour is measured as the number of employees excluding the number of R\&D employees (in logs). The latter correction is made to avoid double counting R\&D employees as part of Labour and as part of R\&D since a substantial proportion of the total $R \& D$ expenditure consists of outlays for $R \& D$ employees (see Cuneo and Mairesse 1995). Schankerman (1981) and Hall and Mairesse (1995) have shown that the estimated elasticity of R\&D capital is downward biased if we do not correct for double counting. Admittedly, we would also have loved to correct Capital for investments in physical capital related to R\&D and Material for material expenses related to $R \& D$ which are usually also included in $R \& D$ expenditure figures. Based on the data at hand, however, we are not able to correct Capital and Material to avoid double counting. However, figures of the R\&D surveys in Germany shows that the majority of R\&D expenditure consists of labour costs $(60 \%)$ whereas investment make up only $7.8 \%$ and material costs $32.2 \%$.

\section{Intangible Inputs}

Which types of intangible assets do we account for? In our main regressions, we distinguish between three broad categories of intangibles: Innovative Capital (IC), Human Capital (HC), and Branding Capital (BC). 
Innovative capital is proxied using three different intangible components: $R \& D$, design \& licenses, and the patent stock. $R \& D$ is defined as the outlays for intramural and extramural R\&D activities in year t per employee (in log). Design \& Licenses (DL) captures innovative capital that is not related to $R \& D$ activities but is related to the expenses for design, external knowledge, and product preparation in the course of innovation activities (per employee, in log.).

Due to data constraints, we cannot further separate these expenses. To avoid double counting we correct for marketing expenses and employee training and education programs related to the introduction of new products. ${ }^{5}$

In addition to the input oriented measures of innovative capital, we use the patent stock $(\mathrm{P})$ as an output oriented variable for a firm's knowledge capital. The patent stock captures the accumulated number of granted patents at the European Patent Office (EPO). We use the perpetual inventory method to construct the patent stock applying a depreciation rate of $15 \%$. In order to account for the skewness of the patent stock we employ patent stock per employee on period $t-1$ as explanatory variable in the regression. Since some firms do not have patents, we additionally include a dummy variable indicating firms without patents.

Starting with the 2007 survey, the MIP also contains information on firm's total marketing expenditure which we employ to proxy reputation or branding capital. Marketing expenditure are defined as the sum of in-house and purchased advertising expenditure, conceptual design of marketing strategies, market and customer demand research and establishment of new distribution channels. Expenditure solely directed at sales and distribution activities are explicitly excluded. Marketing expenses are also scaled by using the number of employees and taking logs to account for the skewness of the distribution. Branding capital can be protected by trademarks, which belong like patents to the family of intellectual property rights. The trademark stock of a firm might proxy two different types of intangibles: First, trademarks directly protect a firm's branding capital and thus the signs and names of its products and services so that it is not possible for other companies to use a confusingly similar mark (Economides, 1998). We use trademark data from the German Patent and Trade Mark Office (DPMA) for national protected trademarks as well as from the Office of Harmonization for the Internal Market (OHIM) for Community trademarks. We calculate the stock of registered trademarks per employee (in $\log$ ) and use the one-year lagged value as an additional variable for branding capital in the regression.

\footnotetext{
${ }^{5}$ For both marketing and training expenditures for innovation, we use the average ratio of these expenses to overall innovation expenditure (IE) in industry $j$ from a prior wave to get expenditures for Design \& Licenses (DL) in the following way:

$$
D L=I E_{i j t}-\overline{\left(\frac{\text { marketing for innovation }}{I E}\right)_{j}} * I E_{i j t}-\overline{\left(\frac{\text { training for innovation }}{I E}\right)_{j}} * I E_{i j t}
$$
}


We follow Black and Lynch (2001) and use two indicators to proxy human capital. The first indicator accounts for the educational level of workers. The share of highskilled labour captures the proportion of employees with a tertiary degree. The second variable is the expenditure for internal and external professional development training. Information on both variables are directly taken from the survey. Note, as for marketing, training expenditure also includes costs for training activities that firms have occurred within innovation projects.

In addition to these three broad categories of intangibles, Corrado et al. (2009) suggested to account for computerized information and organizational capital as well. Unfortunately, the survey does not contain information on software investments. Regarding organizational capital, we do not have quantitative information but only qualitative measures. We use three dummy variables that indicate whether the firm has introduced new business processes (e.g. quality management systems, supply chain management systems, lean production, matrix organization), new methods of workplace organization (e.g. decentralization or centralization of decision making, job rotation, team work, basic realignment of departments), and new types of external relationships (e.g. alliances, cooperation agreements, outsourcing, customer relationship, supplier integration) in a three-year period t-2 to t. We interpret the introduction of one of these events as an improvement in organizational capital. Since this information is only available for the 2006, 2008 and 2010 cross-section, we leave out organizational capital in the main model but include it in a robustness analysis in section 6 .

\section{Control Variables}

As additional control variables we include the export intensity and we use dummy variables indicating whether the company's headquarter is located in East Germany and whether a company is part of a group as well as time and industry dummies. A detailed definition of the variables employed in the empirical analysis is provided by Table 12 in the Appendix.

\section{Stylized Facts on Firm-Level Investments in In- tangibles}

This section presents some stylized facts on firm-level investment in intangibles and its relationship to productivity. Table 1 starts with reporting the proportion of firms that have invested in different types of intangible assets. It turns out that by far not all firms invest in all components of intangible assets.

Regarding innovative capital, for instance, only about 42 percent of the firms in our sample report positive expenditures in $R \& D$ and only 18 percent have at least 
Table 1: Proportion of Firms with Intangibles by Industries

\begin{tabular}{lccccccc}
\hline & $\begin{array}{c}\text { Full sample } \\
\text { Mean }\end{array}$ & $\begin{array}{c}\text { O-M } \\
\text { Mean }\end{array}$ & $\begin{array}{c}\text { LT-M } \\
\text { Mean }\end{array}$ & $\begin{array}{c}\text { MT-M } \\
\text { Mean }\end{array}$ & $\begin{array}{c}\text { HT-M } \\
\text { Mean }\end{array}$ & $\begin{array}{c}\text { KI-S } \\
\text { Mean }\end{array}$ & $\begin{array}{c}\text { LKI-S } \\
\text { Mean }\end{array}$ \\
\hline $\begin{array}{l}\text { Innovative Capital } \\
\quad \text { R\&D }\end{array}$ & 0.42 & 0.11 & 0.35 & 0.59 & 0.81 & 0.36 & 0.15 \\
$\quad \begin{array}{l}\text { Design \& Licenses } \\
\quad \text { Patent Stock }\end{array}$ & 0.36 & 0.20 & 0.33 & 0.46 & 0.47 & 0.33 & 0.23 \\
$\quad \begin{array}{l}\text { Human Capital } \\
\quad \text { Training }\end{array}$ & 0.18 & 0.06 & 0.12 & 0.35 & 0.43 & 0.06 & 0.04 \\
$\quad$ High Skilled Labour & 0.88 & 0.89 & 0.78 & 0.89 & 0.93 & 0.88 & 0.89 \\
$\quad \begin{array}{l}\text { Branding Capital } \\
\text { Marketing }\end{array}$ & 0.88 & 0.83 & 0.82 & 0.92 & 0.95 & 0.90 & 0.83 \\
$\quad \begin{array}{l}\text { Trademark Stock } \\
\text { Organizational Capital }\end{array}$ & 0.82 & 0.72 & 0.82 & 0.83 & 0.91 & 0.83 & 0.80 \\
$\quad \begin{array}{l}\text { Business Process } \\
\quad \text { Labour Organization }\end{array}$ & 0.37 & 0.24 & 0.40 & 0.44 & 0.60 & 0.30 & 0.23 \\
$\quad$ Relation Management & 0.39 & 0.26 & 0.31 & 0.44 & 0.54 & 0.41 & 0.34 \\
\hline Observations & 0.25 & 0.28 & 0.33 & 0.38 & 0.42 & 0.38 & 0.31 \\
\hline
\end{tabular}

Notes: LT-M, MT-M, and HT-M denote low-tech manufacturing (including energy and construction), medium-tech manufacturing, and high-tech manufacturing. KI-S denotes knowledgeintensive and LKI-S low-knowledge-intensive services.

Source: ZEW: Mannheim Innovation Panel, surveys 2007-2011.

one granted patent at the European Patent Office (EPO). Around 36 percent report positive expenditures for Design \& Licenses. Much more common are investments in branding and human capital. About 82 percent of the companies invest in their reputation by spending in marketing activities. However, only 37 percent of the firms in the sample protect their branding capital by means of a registered Community or German trademark. The most common investment in intangibles relates to human capital. About 88 percent of the firms employ high skilled employees. This is further enhanced through investment in professional training by 88 percent of the firms in our sample. In contrast to investment in branding and human capital, firms invest less often in the third type of economic competences (Corrado et al., 2009), i.g. less frequently in organizational capital. Around one third of the companies invested in business processes (39 percent) and new methods of workplace organization (36 percent) and about one quarter in new external relations ( 25 percent). We furthermore find that many firms have more than one type of intangible capital. Using the three broad categories IC, BC, HC, we find that only a very small proportion of firms $(1.8 \%)$ do not invest in intangibles at all. About $11 \%$ of the firms invest in one type of intangibles. $35.8 \%$ of the firms invest in two types and more than half of the firms have all three types of intangibles (51.3\%). For the 2006, 2008, 2010 subsample we even find that one quarter of firms $(25.4 \%)$ have invested in all four types of intangibles (IC, BC, HC, OC). The correlation matrix in Appendix 14 provides evidence on the pairwise correlation of the usage of the various types of in- 
tangible assets. Highest correlation is found for R\&D and Design \& Licenses, R\&D and Patents, and Patents and Trademarks.

Table 1 furthermore provides an industry breakdown for six broad industry categories. As expected, the proportion of firms engaged in Innovative Capital is highest in high-tech manufacturing, followed by medium-tech manufacturing and knowledgeintensive service industries. The heterogeneity across sectors is large for $R \& D$ and patents, but much smaller for Design \& Licenses. The table reveals a clear ranking: Except for patents and trademarks, we find the share of firms having invested in intangibles to be highest in high-tech manufacturing, followed by medium-tech manufacturing and knowledge intensive service. For patents and trademarks, shares are also highest in high-tech manufacturing and medium-tech manufacturing but followed by low-tech manufacturing.

Table 2: Descriptive Statistics of Main Variables

\begin{tabular}{|c|c|c|c|c|c|c|c|}
\hline & $\begin{array}{c}(1) \\
\text { Median }\end{array}$ & $\begin{array}{l}(2) \\
\text { Mean }\end{array}$ & $\begin{array}{l}(3) \\
\text { SD }\end{array}$ & $\begin{array}{l}(4) \\
\text { Min }\end{array}$ & $\begin{array}{l}(5) \\
\operatorname{Max}\end{array}$ & $\begin{array}{c}(6) \\
\text { Mean cL }\end{array}$ & $\begin{array}{c}(7) \\
\text { Mean IC }\end{array}$ \\
\hline \multicolumn{8}{|l|}{ Productivity } \\
\hline Productivity & 124.93 & 202.95 & 329.71 & 1.67 & 6990.9 & 216.90 & - \\
\hline \multicolumn{8}{|l|}{ Traditional Inputs } \\
\hline Capital & 26.35 & 129.52 & 452.80 & 0.049 & 14696.4 & 134.69 & - \\
\hline Labour & 53.00 & 872.91 & 6260.66 & 1 & 174773 & 825.00 & - \\
\hline Material & 45.82 & 102.49 & 224.78 & 0.048 & 4944.6 & 107.56 & - \\
\hline \multicolumn{8}{|l|}{ Innovative Capital } \\
\hline$R \& D$ & 0.00 & 2.87 & 8.74 & 0 & 290.3 & 5.08 & 12.15 \\
\hline Design \& Licenses & 0.00 & 1.21 & 9.80 & 0 & 921.6 & 1.52 & 4.24 \\
\hline Patent Stock & 0.00 & 0.00 & 0.03 & 0 & 1.65 & 0.01 & 0.05 \\
\hline \multicolumn{8}{|l|}{ Human Capital } \\
\hline Training & 0.25 & 0.50 & 0.86 & 0 & 24.7 & 0.58 & 0.66 \\
\hline High Skilled Labour & 0.10 & 0.20 & 0.23 & 0 & 1 & 0.20 & 0.23 \\
\hline \multicolumn{8}{|l|}{ Branding Capital } \\
\hline Marketing & 0.33 & 1.83 & 6.36 & 0 & 200.6 & 2.07 & 2.51 \\
\hline Trademark Stock & 0.00 & 0.03 & 0.12 & 0 & 4 & 0.04 & 0.10 \\
\hline
\end{tabular}

Notes: The Table shows raw values in thousands of Euros. This is for the purposes of transparency only; the logarithmized variables are included in the models. The only exceptions are High Skilled Labour, which is a proportion between 0 and 1 and Labour which is measured in number of employees. Patents and Trademarks are measured as stocks per employee. Column (6) provides the sample means using the corrected labour measure as denominator in the per capita calculations and column (7) the truncated mean for firms with non-zero intangible capital.

Source: ZEW: Mannheim Innovation Panel, surveys 2007-2011.

Table 2 furthermore reports quantitative measures on intangible assets. On average firms spend 2.87 thousand Euro per employee on R\&D and 2.1 thousand Euro on Design \& Licenses. Marketing expenditures are in between, amounting to 1.83 thousand Euro per employee. On average, less is spent on training activities (0.5 thousand Euro per employee).

The median of labour productivity amounts to 125 thousand Euro while the mean productivity is much higher with 203 thousand Euro. The per-employee level statis- 
tics suggest considerable departures from normality: the means are almost always larger than the corresponding medians.

As already mentioned, in the econometric analyse we use Labour which is corrected for R\&D employees to avoid double counting. This correction affects all per capita variables. While column (2) reports the mean values using the total number of employees in the denominator, column (6) additionally provides mean values using the corrected labour measure which are used in the empirical regression. As the denominator remained the same through the correction or became smaller, we see higher average values. This is particularly true for R\&D. Since a considerable proportion of firms do not invest in intangible assets, column (7) provides the average intangible capital per employee for those firms that invest in the respective intangibles. Investing firms spend the highest amounts into R\&D and Design \& Licenses, followed by Marketing. The median value of zero for all components of innovative capital and for the trademark stock point to the fact that less than half of the firms invest in those intangible assets.

Table 3: Differences in Firm Productivity by Intangible Assets

\begin{tabular}{lccc}
\hline & Non-Investors & Investors & High investing firms \\
\hline Innovative Capital & & & \\
R\&D & 196.5 & $245.4^{* * *}$ & 302.8 \\
Design \& Licenses & 199.2 & $248.7^{* * *}$ & 282.8 \\
Patent Stock & 200.4 & $290.5^{* * *}$ & 279.1 \\
Human Capital & & & \\
Training & 151.0 & $226.2^{* * *}$ & 279.2 \\
$\quad$ High Skilled Labour & 143.0 & $226.7^{* * *}$ & 255.3 \\
Branding Capital & & & \\
Marketing & 188.4 & $223.0^{* * *}$ & 278.4 \\
$\quad$ Trademark Stock & 176.9 & $286.5^{* * *}$ & 284.8 \\
Organizational Capital & & & \\
$\quad$ Business Process & 199.0 & $225.4^{* * *}$ & \\
$\quad$ Labour Organization & 199.3 & $227.2^{* * *}$ & \\
$\quad$ Relation Management & 197.4 & $244.4^{* * *}$ & \\
\hline
\end{tabular}

Do firms that invest in intangible assets differ in productivity? The descriptive statistics of Table 3 and mean difference tests support this view. For each category we find average labour productivity to be higher in firms that have invested in this type of intangible capital than in non-investing firms. The mean differences are in each case statistically significant. Firms that invest a disproportionately large amount in the respective intangible asset (i.e. above the mean), have an even higher average productivity. Interestingly, the only exception are the intellectual property rights, patents and trademarks for which we find productivity some what smaller in high-investing firms than in low-investing firms. The observed productivity differences between investors and non-investors might be driven by other observed or unobserved individual characteristics. Therefore, we use econometric techniques to analyse whether and to what extent this result holds in section 6 . 


\section{Econometric Results}

\subsection{Estimation Method}

In order to estimate the production function we have used various parametric and non-parametric econometric estimation methods. The empirical results presented below are based on our preferred approach of Olley and Pakes (1996). This approach solves both the endogeneity problem due to simultaneity of input and output decision and the selection problem that arises in the estimation of production functions. The endogeneity problem arises since the input factors are chosen by the firm and the firm has knowledge (at least to some extent) of its productivity shock when making these input choices. As a result, the firm's input choices will likely be correlated with its productivity (Marschak and Andrews, 1944). This implies that the input factors are correlated with the error term of the productivity equation. In this case, OLS is an inappropriate estimation method as it delivers inconsistent estimates. The variable inputs like labour and materials are expected to have an upward bias and the coefficients associated with quasi-fixed inputs like capital are expected to be biased downwards (Olley and Pakes, 1996). The method by Olley and Pakes (1996) solves the simultaneity issue by using the observable investment decision of the firm to proxy for unobserved productivity shocks in a control function approach.

The empirical analysis below is conducted in four steps. In section 6.2 we focus on the effect of innovative, human and branding capital on productivity. Section 6.3 is devoted to some robustness checks regarding the estimation method and the measurement of intangible capital and productivity. In section 6.4 we additionally explore the role organizational capital plays for productivity. Finally, in section 6.5 we investigate whether investments in different kinds of intangible assets are complements or substitutes.

\subsection{Effect of Intangibles on Productivity}

Table 4 provides the estimation results of equations (4) and (7), the first and second stage of our estimation procedure. Column (1) presents the estimates of a production function using solely the traditional input factors whereas the estimates in Column (2) additionally account for a set of control variables. Physical Capital and Material turn out to be highly significant with an estimated output elasticity of about 0.13 and 0.38 . The significantly positive coefficient of labour in Column (1) becomes significantly negative after including the controls indicating slightly decreasing returns to scale. The control variables further show that the productivity level is (still) lower in East Germany (the former GDR), that a firm which belongs to a group has synergy advantages, and that a higher export intensity is related to higher productivity levels. 
Table 4: Effect of Intangibles on Firm-Level Productivity (TFP)

\begin{tabular}{|c|c|c|c|c|c|c|}
\hline & $\begin{array}{c}(1) \\
\text { 1st stage }\end{array}$ & $\begin{array}{c}(2) \\
\text { 1st stage }\end{array}$ & $\begin{array}{c}(3) \\
\text { 2nd stage } \\
\end{array}$ & $\begin{array}{c}(4) \\
\text { 2nd stage }\end{array}$ & $\begin{array}{c}(5) \\
\text { 2nd stage } \\
\end{array}$ & $\begin{array}{c}(6) \\
\text { 2nd stage }\end{array}$ \\
\hline Capital & $\begin{array}{l}0.097^{* * *} \\
(0.022)\end{array}$ & $\begin{array}{l}0.131^{* * *} \\
(0.038)\end{array}$ & & & & \\
\hline Labour & $\begin{array}{l}0.019^{* * *} \\
(0.003)\end{array}$ & $\begin{array}{c}-0.012^{* * *} \\
(0.004)\end{array}$ & & & & \\
\hline Material & $\begin{array}{l}0.391^{* * *} \\
(0.007)\end{array}$ & $\begin{array}{l}0.378^{* * *} \\
(0.007)\end{array}$ & & & & \\
\hline \multicolumn{7}{|l|}{ Innovative Capital } \\
\hline $\mathrm{R} \& \mathrm{D}$ & & & $\begin{array}{l}0.056^{* * *} \\
(0.004)\end{array}$ & & & $\begin{array}{l}0.031^{\text {*** }} \\
(0.005)\end{array}$ \\
\hline Design \& Licenses & & & $\begin{array}{l}0.008^{* * *} \\
(0.003)\end{array}$ & & & $\begin{array}{c}0.005^{*} \\
(0.003)\end{array}$ \\
\hline Patent Stock & & & $\begin{array}{l}0.015^{* * *} \\
(0.005)\end{array}$ & & & $\begin{array}{c}0.005 \\
(0.005)\end{array}$ \\
\hline \multicolumn{7}{|l|}{ Human Capital } \\
\hline Training & & & & $\begin{array}{l}0.061^{* * *} \\
(0.004)\end{array}$ & & $\begin{array}{l}0.039^{* * *} \\
(0.005)\end{array}$ \\
\hline High Skilled Labour & & & & $\begin{array}{l}0.350^{* * *} \\
(0.026)\end{array}$ & & $\begin{array}{l}0.266^{* * *} \\
(0.026)\end{array}$ \\
\hline \multicolumn{7}{|l|}{ Branding Capital } \\
\hline Marketing & & & & & $\begin{array}{l}0.047^{* * *} \\
(0.003)\end{array}$ & $\begin{array}{l}0.030^{* * *} \\
(0.003)\end{array}$ \\
\hline Trademark Stock & & & & & $\begin{array}{l}0.032^{* * *} \\
(0.005)\end{array}$ & $\begin{array}{l}0.022^{* * *} \\
(0.005)\end{array}$ \\
\hline \multicolumn{7}{|l|}{ Controls } \\
\hline East Germany & & $\begin{array}{c}-0.156^{* * *} \\
(0.010)\end{array}$ & $\begin{array}{c}-0.007 \\
(0.010)\end{array}$ & $\begin{array}{c}-0.014 \\
(0.010)\end{array}$ & $\begin{array}{c}0.018^{*} \\
(0.010)\end{array}$ & $\begin{array}{c}-0.006 \\
(0.010)\end{array}$ \\
\hline Group & & $\begin{array}{l}0.147^{* * *} \\
(0.013)\end{array}$ & $\begin{array}{r}-0.020^{*} \\
(0.011)\end{array}$ & $\begin{array}{c}-0.029^{* * *} \\
(0.010)\end{array}$ & $\begin{array}{r}-0.020^{*} \\
(0.011)\end{array}$ & $\begin{array}{c}-0.034^{* * *} \\
(0.011)\end{array}$ \\
\hline Export & & $\begin{array}{l}0.160^{* * *} \\
(0.024)\end{array}$ & $\begin{array}{c}-0.073^{* * *} \\
(0.020)\end{array}$ & $\begin{array}{c}-0.039^{* *} \\
(0.019)\end{array}$ & $\begin{array}{c}-0.039^{* *} \\
(0.019)\end{array}$ & $\begin{array}{c}-0.084^{* * *} \\
(0.020)\end{array}$ \\
\hline W_Time & & 0.022 & 0.824 & 0.967 & 0.000 & 0.000 \\
\hline W_Industry & & 0.000 & 0.000 & 0.000 & 0.000 & 0.000 \\
\hline Adjusted R̂̂े & 0.633 & 0.702 & 0.026 & 0.044 & 0.035 & 0.066 \\
\hline Observations & 11,021 & 11,021 & 11,021 & 11,021 & 11,021 & 11,021 \\
\hline
\end{tabular}

Notes: Significance levels: ${ }^{* * *} \mathrm{p}<0.01,{ }^{* *} \mathrm{p}<0.05,{ }^{*} \mathrm{p}<0.1$. Standard errors in parentheses. Estimation method: Olley and Pakes (1996). The number of observations refers to the first stage of the OP regression. Due to the time structure, 5,453 observations remain for the non-linear regression of the second stage of the OP approach. Column (1) and (2) provide bootstrapped standard errors in parentheses. The TFP regression additionally includes six dummies indicating R\&D, Design \& Licenses, Patent Stock, Firm-specific Training, Marketing, and Trademark Stock is zero. Column (3) to (6) provide robust standard errors in parentheses.

In the second stage, TFP (Total Factor Productivity) is regressed on various components of intangible assets. ${ }^{6}$ We first examine separately the three broad intangible

\footnotetext{
${ }^{6}$ Many companies report no investment for some or all intangible assets. In order to deal it, we replace the log values with a constant (here: zero) and additionally add dummy variables for non-investing observations. In this way, the estimated output elasticity is unaffected by the choice about the constant.
} 
asset categories. We restrict the specification to the three components of Innovative Capital in Column (3), to those of Human Capital in Column (4), and to the components of Branding Capital in Column (5). Finally, all intangible asset components are jointly investigated in Column (6). It turns out that all components of Innovative Capital in Column (3), namely R\&D, Design \& Licenses, and Patent Stock, are highly significant in explaining TFP levels in German firms. The productivityenhancing effect of $R \& D$ is in line with many other empirical studies (Hall et al., 2010). Moreover, our findings show that also non-R\&D-related investment in innovative capital like Design \& Licenses are conducive to productivity. Note that we cannot directly compare the magnitude of the effect of tangible capital and intangible components since the latter are proxied by expenses. Column (4) shows that both components of Human Capital, Training and High Skilled Labour, also significantly raise productivity. The same is true for both components of Branding Capital in Column (5). Marketing and Trademark Stocks have a positive and seizable effect on TFP.

It is interesting to note that all coefficients of intangible capital get considerably smaller, when including the other types of intangibles, shown in Column (6). This reflects an omitted variable bias problem in Column (3) to (5). As the omitted variable bias formula states, positively correlated variables (like the intangible assets in our sample) that are left out in the regression cause an overestimation of the effect of included variables. The estimated effect for $R \& D$ is, for instance, overestimated by $80 \%$ while R\&D and Design and Licenses are still significant the effect of the Patent Stock is no longer significant in the joint regression. This is an important message in itself, as it implies that output elasticities of individual intangible components are overestimated, when not all inputs are properly considered. Admittedly, this restriction applies (to a lesser extent) also to our estimates because intangible assets like software and databases or organizational capital are not considered due to data limitations. However, the extent of the bias in our more complete set of intangible assets should be rather limited. To sum up, our results strikingly show that except for Patent Stock, all intangible components are productivity-enhancing.

We also aim at shedding light on the question of whether the impact of intangibles differ across industries. In order to do so, we split the sample into various subsamples. Our results show some interesting findings. ${ }^{7}$ First, it is corroborated that human capital has a stimulating effect on productivity across all industries. Interestingly, the average effect is stronger in more labour-intensive service industries compared manufacturing industries. Likewise, branding capital turns out to be positive related to productivity in all manufacturing and service industries. Rather puzzling is the finding that trademarks do not significantly enter the productivity equation, neither for medium-tech and high-tech, nor for knowledge-intensive firms.

\footnotetext{
${ }^{7}$ Detailed results are presented in Table 16 and Table 17 in the Appendix.
} 
Trademarks are however productivity enhancing in industries of low level of technological intensity (low-tech manufacturing and low-knowledge-intensive services). The impact of marketing expenditure is highly significant across all industries and of similar magnitude in all industries except for medium-tech manufacturing. Third, the largest variations across industries stick out for our proxies measuring different aspects of innovative capital. Our results are sensible in that we find that R\&D significantly boosts productivity in all manufacturing industries and knowledgeintensive services. We find a long-term effect of innovative capital in a sense that accumulated granted patents stimulate current productivity in high-tech manufacturing as well as in knowledge-intensive and low-knowledge-intensive services. In low-knowledge intensive services such as transport or wholesale the picture that emerges is more obscure. Investments in R\&D do not lead to productivity increases per se but only if firms have successfully transformed $R \& D$ investments into granted patents. Our results further provide interesting insights into the role of design and licenses. We find them to largely matter only in knowledge-intensive services but not in manufacturing industries.

\subsection{Robustness Checks}

\subsubsection{Several Productivity Estimation Methods}

The econometric literature provides several approaches to deal with the endogeneity issue in the context of production function estimation. Eberhardt and Helmers (2010) emphasize that the most popular estimators for Cobb-Douglas production functions are conceptually quite similar but that in practice the choice of the estimation method might considerably influence the empirical results. We examine the influence of the estimation method on our empirical results by comparing alternative parametric (OLS, FE) and non-parametric (OP, LP) estimation methods. Table 5 provides the results of the second stage, the regression of TFP on our set of intangible assets.

The OLS estimates are presented in Column (1). As already stressed, they are likely to be biased. One traditional (parametric) solution to the endogeneity problem is fixed effects (FE) estimation which makes explicit use of firm panel data. The fundamental assumption behind this model is that unobserved productivity is constant over time. As reported in other studies, we got unreasonable large coefficients for labour in the FE estimates and therefore follow the suggestions by Mairesse and Griliches (1998) and assume constant return to scale. The FE estimates in Column (2) of Table 5 confirm a strong significant impact of R\&D, Design \& Licenses, Human and Brand Capital on productivity. However the effect of Human and Brand Capital is larger in the FE estimation.

An alternative solution to FE and OP is provided by Levinsohn and Petrin (2003), 
Table 5: Robustness Check: Parametric and Non-Parametric Estimation Methods

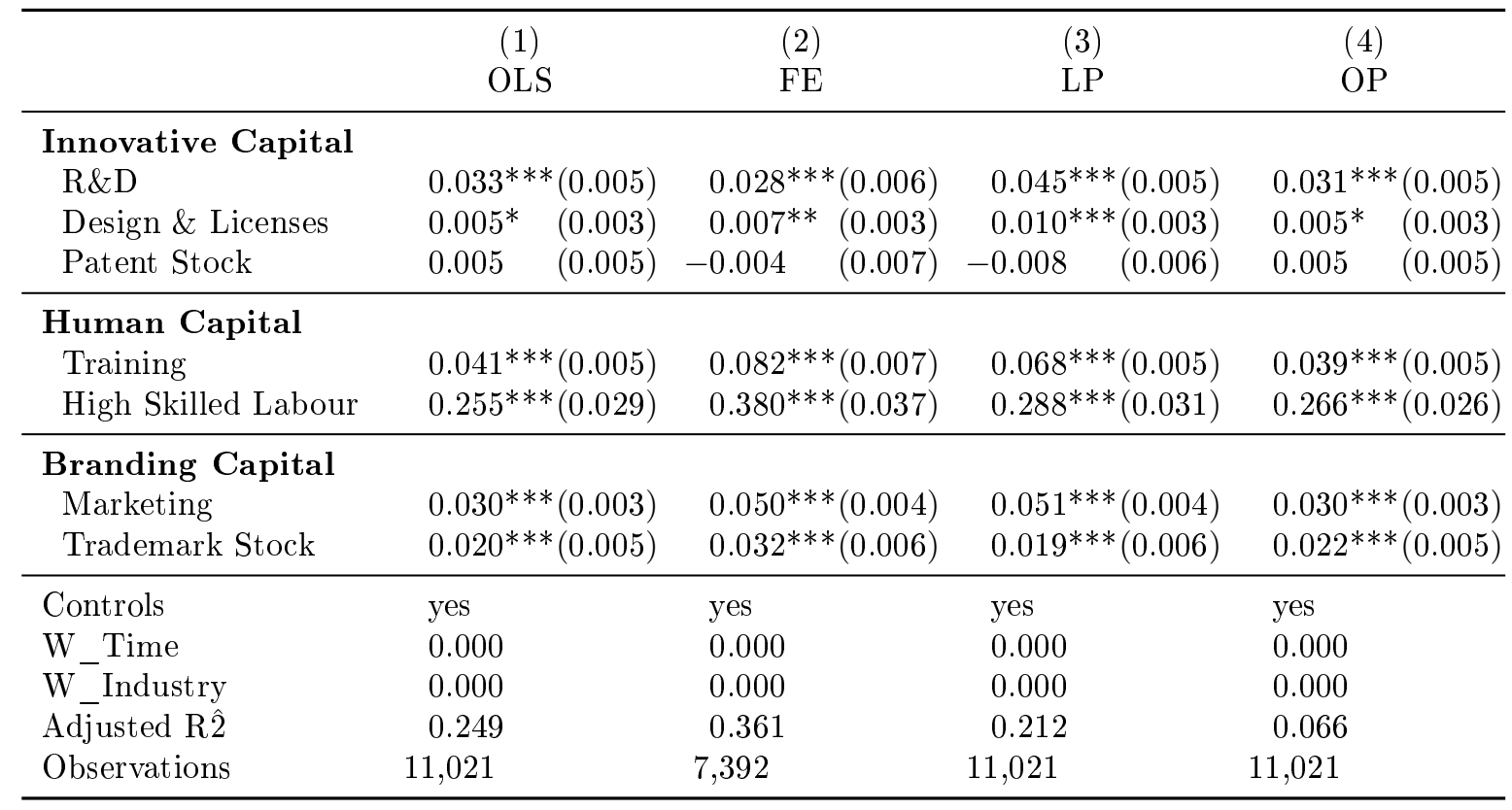

Notes: Significance levels: $* * * \mathrm{p}<0.01,{ }^{*} \mathrm{p}<0.05,{ }^{*} \mathrm{p}<0.1$. Standard errors in parentheses. Estimation method: OLS, FE (fixed effects), LP (Levinsohn and Petrin, 2003) and OP (Olley and Pakes, 1996). Regression additionally includes the standard control variables (East, Group, and Export) and six dummies indicating R\&D, Design \& Licenses, Patent Stock, Firm-specific Training, Marketing, and Trademark Stock is zero.

who build on the Olley and Pakes (1996) approach. Levinsohn and Petrin (2003) (LP) propose the use of intermediate inputs instead of investment to back out productivity shocks observed by the firm. Column (3) shows that LP also provides qualitatively the same results as OP and FE. Comparing LP and OP, we generally find somewhat larger effects of intangibles using LP, except for Trademarks. Qualitatively, FE yield the same results as OP and OLS.

Overall, the coefficient of $R \& D$ is largest in the LP estimation. The same is true for Design \& Licenses, whereas the effect of Training and High Skilled Labour is largest in the FE estimation. But all in all, accounting for endogeneity by using the OP estimation method provides very similar results to the alternative estimation methods. The estimated productivity effects of intangible assets remain quite stable and, with the exception of the Patent Stock, highly significant.

\subsubsection{Labour Productivity vs. Total Factor Productivity}

Our estimation approach is sequential and consists of two stages: In the first stage, firm-level TFP is estimated and the second stage investigates the impact of intangible assets on TFP. An alternative widely used approach uses a standard CobbDouglas production function augmented with intangible capital stocks (Griliches, 1979; Hall and Mairesse, 2006). The augmented production function is estimated in one stage. 
In the case of our empirical setting, this results into the following equation:

$$
\begin{array}{r}
q_{i t}-l_{i t}=\beta_{0}+(\mu-1) l_{i t}+\beta_{k}\left(k_{i t}-l_{i t}\right)+\beta_{m}\left(m_{i t}-l_{i t}\right) \\
+\gamma_{1}\left(i c_{i t}-l_{i t}\right)+\gamma_{2}\left(h c_{i t}-l_{i t}\right)+\gamma_{3}\left(b c_{i t}-l_{i t}\right)+\gamma_{4}\left(o c_{i t}-l_{i t}\right)+\omega_{i t}+\eta_{i t}
\end{array}
$$

Hence, we re-estimated our preferred model specification (Column (6) of Table 4) in one step. Table 6 shows that the estimated coefficients and standard errors of the intangible assets are roughly the same for both approaches. The estimated coefficients of the intangible assets are slightly smaller in the two-stage TFP approach, while the capital coefficient is slightly larger. This points to a correlation of intangible and physical capital. In contrast to the two step results, the one-step approach indicates constant returns to scale.

\begin{tabular}{|c|c|c|c|c|c|c|}
\hline \multirow{4}{*}{$\begin{array}{l}\text { Capital } \\
\text { Labour } \\
\text { Material }\end{array}$} & \multicolumn{2}{|c|}{$\begin{array}{c}(1) \\
\text { 1st stage }\end{array}$} & \multicolumn{2}{|c|}{$\begin{array}{c}(2) \\
\text { 2nd stage (TFP) }\end{array}$} & \multicolumn{2}{|c|}{$\begin{array}{c}\text { Single-Stage Approach } \\
(3) \\
\text { Lab. Prod. }\end{array}$} \\
\hline & $0.131^{* * *}$ & $(0.038)$ & & & $0.116^{* * *}$ & $(0.036)$ \\
\hline & $-0.012^{* * *}$ & $(0.004)$ & & & -0.002 & $(0.004)$ \\
\hline & $0.378^{* * *}$ & $(0.007)$ & & & $0.357^{* * *}$ & $(0.007)$ \\
\hline \multicolumn{7}{|l|}{ Innovative Capital } \\
\hline R\&D & & & $0.031^{* * *}$ & $(0.005)$ & $0.033^{* * *}$ & $(0.005)$ \\
\hline Design \& Licenses & & & $0.005^{*}$ & $(0.003)$ & $0.005^{*}$ & $(0.003)$ \\
\hline Patent Stock & & & 0.005 & $(0.005)$ & 0.004 & $(0.005)$ \\
\hline \multicolumn{7}{|l|}{ Human Capital } \\
\hline Training & & & $0.039^{* * *}$ & $(0.005)$ & $0.044^{* * *}$ & $(0.005)$ \\
\hline High Skilled Labour & & & $0.266^{* * *}$ & $(0.026)$ & $0.263^{* * *}$ & $(0.028)$ \\
\hline \multicolumn{7}{|l|}{ Branding Capital } \\
\hline Marketing & & & $0.030 * * *$ & $(0.003)$ & $0.034^{* * *}$ & $(0.003)$ \\
\hline Trademark Stock & & & $0.022^{* * *}$ & $(0.005)$ & $0.025^{* * *}$ & $(0.006)$ \\
\hline \multicolumn{7}{|l|}{ Controls } \\
\hline East Germany & $-0.156^{* * *}$ & $(0.010)$ & -0.006 & $(0.010)$ & $-0.160^{* * *}$ & $(0.010)$ \\
\hline Group & $0.147^{* * *}$ & $(0.013)$ & $-0.034^{* * *}$ & $(0.011)$ & $0.122^{* * *}$ & $(0.012)$ \\
\hline Export & $0.160^{* * *}$ & $(0.024)$ & $-0.084^{* * *}$ & $(0.020)$ & $0.084^{* * *}$ & $(0.024)$ \\
\hline W_Time & 0.022 & & 0.000 & & 0.000 & \\
\hline $\mathrm{W}_{-}^{-}$Industry & 0.000 & & 0.000 & & 0.000 & \\
\hline 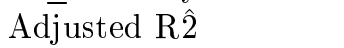 & 0.702 & & 0.066 & & 0.724 & \\
\hline Observations & 11,021 & & 11,021 & & 11,021 & \\
\hline
\end{tabular}

Table 6: Robustness Check: Labour Productivity vs. TFP

Notes: Significance levels: ${ }^{* * *} \mathrm{p}<0.01,{ }^{* *} \mathrm{p}<0.05,{ }^{*} \mathrm{p}<0.1$. Standard errors in parentheses. Estimation method: Olley and Pakes (1996). The number of observations refers to the first stage regression. In the nonlinear regression of the second stage remain due to the time structure 5,453 observations. Regression additionally includes six dummies indicating R\&D, Design \& Licenses, Patent Stock, Firm-specific Training, Marketing, and Trademark Stock is zero. 


\subsubsection{Revenue vs. Value Added}

Instead of using labour productivity, measured as sales per employee, the production function could also be specified in terms of value added:

$$
v a_{i t}-l_{i t}=\beta_{0}+\beta_{k}\left(k_{i t}-l_{i t}\right)+\omega_{i t}+\eta_{i t}
$$

where $v a_{i t}$ denotes value added, defined as sales less material costs (in logs). The sample is slightly reduced since value added is negative for 102 observations and the corresponding logarithm is not defined. The exclusion of this special group of observations could potentially affect the estimates, but the results in Table 7 show only minor deviation of the results from those of the full sample (Table 4). Qualitatively the value added approach yields the same results, i.e. except for patents all intangible asset components are highly significant. But the coefficients change in magnitude. The capital coefficient is almost twice as large in the value added specification and the all intangible asset components are considerably larger than in the revenue specification. 
Table 7: Robustness Check: Value Added

\begin{tabular}{|c|c|c|c|c|}
\hline & \multicolumn{2}{|c|}{ Revenue } & \multicolumn{2}{|c|}{ Value Added } \\
\hline & $\begin{array}{c}(1) \\
\text { 1st stage }\end{array}$ & $\begin{array}{c}(2) \\
\text { 2nd stage }\end{array}$ & $\begin{array}{c}(3) \\
\text { 1st stage }\end{array}$ & $\begin{array}{c}(4) \\
\text { 2nd stage }\end{array}$ \\
\hline Capital & $\begin{array}{l}0.129 * * * \\
(0.029)\end{array}$ & & $\begin{array}{l}0.239^{* * *} \\
(0.040)\end{array}$ & \\
\hline Labour & $\begin{array}{c}-0.013^{* * *} \\
(0.004)\end{array}$ & & $\begin{array}{c}-0.021^{* * *} \\
(0.005)\end{array}$ & \\
\hline Material & $\begin{array}{l}0.381^{* * *} \\
(0.007)\end{array}$ & & & \\
\hline \multicolumn{5}{|l|}{ Innovative Capital } \\
\hline $\mathrm{R} \& \mathrm{D}$ & & $\begin{array}{l}0.029^{* * *} \\
(0.005)\end{array}$ & & $\begin{array}{l}0.044^{* * *} \\
(0.006)\end{array}$ \\
\hline Design \& Licenses & & $\begin{array}{l}0.005^{* *} \\
(0.003)\end{array}$ & & $\begin{array}{l}0.009^{* * *} \\
(0.003)\end{array}$ \\
\hline Patent Stock & & $\begin{array}{c}0.006 \\
(0.005)\end{array}$ & & $\begin{array}{c}0.012 \\
(0.007)\end{array}$ \\
\hline \multicolumn{5}{|l|}{ Human Capital } \\
\hline Training & & $\begin{array}{l}0.038^{* * * *} \\
(0.005)\end{array}$ & & $\begin{array}{l}0.063^{* * *} \\
(0.006)\end{array}$ \\
\hline High Skilled Labour & & $\begin{array}{l}0.279^{* * *} \\
(0.026)\end{array}$ & & $\begin{array}{l}0.387^{* * *} \\
(0.036)\end{array}$ \\
\hline \multicolumn{5}{|l|}{ Branding Capital } \\
\hline Marketing & & $\begin{array}{l}0.031^{* * *} \\
(0.003)\end{array}$ & & $\begin{array}{l}0.048^{* * *} \\
(0.004)\end{array}$ \\
\hline Trademark Stock & & $\begin{array}{l}0.021^{* * *} \\
(0.005)\end{array}$ & & $\begin{array}{l}0.044^{* * *} \\
(0.007)\end{array}$ \\
\hline \multicolumn{5}{|l|}{ Controls } \\
\hline East Germany & $\begin{array}{c}-0.156^{* * *} \\
(0.010)\end{array}$ & $\begin{array}{c}-0.006 \\
(0.010)\end{array}$ & $\begin{array}{c}-0.249^{* * *} \\
(0.014)\end{array}$ & $\begin{array}{c}-0.007 \\
(0.014)\end{array}$ \\
\hline Group & $\begin{array}{l}0.151^{* * *} \\
(0.012)\end{array}$ & $\begin{array}{c}-0.035^{* * *} \\
(0.011)\end{array}$ & $\begin{array}{l}0.209^{* * *} \\
(0.017)\end{array}$ & $\begin{array}{c}-0.063^{* * *} \\
(0.015)\end{array}$ \\
\hline Export & $\begin{array}{l}0.174^{* * *} \\
(0.022)\end{array}$ & $\begin{array}{l}-0.088^{* * * *} \\
(0.019)\end{array}$ & $\begin{array}{l}0.256^{* * *} \\
(0.029)\end{array}$ & $\begin{array}{c}-0.146^{* * *} \\
(0.027)\end{array}$ \\
\hline W_Time & 0.012 & 0.000 & 0.054 & 0.000 \\
\hline $\mathrm{W}^{-}$Industry & 0.000 & 0.000 & 0.000 & 0.000 \\
\hline Adjusted R̂े & 0.710 & 0.069 & 0.361 & 0.092 \\
\hline Observations & 10,919 & 10,919 & 10,919 & 10,919 \\
\hline
\end{tabular}

Notes: Significance levels: ${ }^{* * *} \mathrm{p}<0.01,{ }^{* *} \mathrm{p}<0.05,{ }^{*} \mathrm{p}<0.1$. Standard errors in parentheses. Estimation method: Olley and Pakes (1996). The number of observations refers to the first stage regression. In the nonlinear regression of the second stage remain due to the time structure 5,354 observations. Regression additionally includes six dummies indicating R\&D, Design \& Licenses, Patent Stock, Firm-specific Training, Marketing, and Trademark Stock is zero.

\subsubsection{Proxy of Capital Stocks: Expenses versus PIM}

In section 6.2, we extended the production function to account for different types of knowledge-related intangible capital. Except for Patents, Trademarks and High Skilled Labour and in contrast to physical capital, however, we have used expenses as proxies for intangible capital stocks up to now. The main reasons are due to the 
fact that the observed time period is rather short in order to construct intangible capital stocks and that the panel is highly unbalanced.

We check whether this difference in measurement impacts our results by using a more balanced subsample. For firms in the subsample we employ the well-known Perpetual Inventory Method (PIM) to derive capital stocks from a flow of investments (Griliches 1979). The intangible capital stock IC of firm $i$ in year $t$ is defined as:

$$
I C_{i, t}=(1-\delta) I C_{i, t-1}+I_{i, t-1}^{R}+I_{i, t-1}^{N}
$$

where $\delta$ is the depreciation rate, and investment $\left(I_{i, t-1}\right)$ of firm $i$ in year $t-1$ is composed of a replacement $\left(I_{i, t-1}^{R}\right)$ and net investment $\left(I_{i, t-1}^{N}\right)$. The replacement investment corresponds to the depreciated capital $\left(\delta I C_{i, t-1}\right)$ and net investment represents the change in the capital stock $\left(\gamma I C_{i, t-1}\right)$. Hence, we can write total investment as:

$$
I_{i, t-1}=\delta I C_{i, t-1}+\gamma I C_{i, t-1}
$$

It could be argued that it takes some time for a firm to achieve the desired optimal level of an intangible capital stock and by assuming that this process follows a partial adjustment mechanism (Chirinko et al. 1999, Nadiri and Rosen 1969), the assumption of constant investment growth $(\gamma)$ might be plausible. Moreover, the closer the capital stock to the long term optimum, the smaller is the net investment and thus the assumption of a constant growth rate is less of a concern.

The assumption of constant growth and depreciation rates leads to the following formula

$$
I C_{i, t}=\frac{I_{i, t}}{\delta+\gamma}
$$

which is widely used to approximate capital stocks. Up to now, we have approximated the capital stock by intangible investment. Multiplying investment with a constant (such as $(\delta+\gamma)^{-1}$ ), as suggested in Equation (12) has no effect on the estimated elasticities in the logarithmic specification of the production function. Thus, our approach is robust against any choice of (constant) depreciation and growth rates.

In contrast to this approach, a longer and more balanced panel allows us to relax the assumption of a constant growth rate but not that of a constant depreciation rate and to use the PIM method to construct capital stocks. We approximate the initial capital stock by multiplying intangible investment with the constant $(\delta+\gamma)^{-1}$. We use intangible-specific depreciation rates $\delta$ following Corrado et al. (2009). Intangiblespecific growth rates $\gamma$ are based on the development of intangible expenditures in 
Germany for each component for the pre-sample period 1995 to 2006 (Crass et al., 2015, see Table 13 in the Appendix). The initial capital stocks are perpetuated using the very same depreciation rates and actual expenditures.

Table 8: Intangibles Proxied by Expenses versus PIM Capital Stocks

\begin{tabular}{|c|c|c|c|c|c|c|}
\hline \multirow[b]{2}{*}{$\begin{array}{l}\text { Capital } \\
\text { Labour } \\
\text { Material }\end{array}$} & \multicolumn{2}{|c|}{$\begin{array}{c}(1) \\
\text { 1st stage }\end{array}$} & \multicolumn{2}{|c|}{$\begin{array}{c}(2) \\
\text { 2nd: Exp. }\end{array}$} & \multicolumn{2}{|c|}{$\begin{array}{c}(3) \\
\text { 2nd: PIM }\end{array}$} \\
\hline & $\begin{array}{c}0.121^{* * *} \\
-0.010^{* *} \\
0.378^{* * *}\end{array}$ & $\begin{array}{l}(0.030) \\
(0.005) \\
(0.009)\end{array}$ & & & & \\
\hline $\begin{array}{l}\text { Innovative Capital } \\
\text { R\&D } \\
\text { Design \& Licenses } \\
\text { Patent Stock }\end{array}$ & & & $\begin{array}{l}0.007 \\
0.000 \\
0.007\end{array}$ & $\begin{array}{l}(0.006) \\
(0.003) \\
(0.007)\end{array}$ & $\begin{array}{c}0.010^{*} \\
-0.006 \\
0.007\end{array}$ & $\begin{array}{l}(0.006) \\
(0.004) \\
(0.007)\end{array}$ \\
\hline $\begin{array}{l}\text { Human Capital } \\
\text { Training } \\
\text { High Skilled Labour }\end{array}$ & & & $\begin{array}{l}0.043^{* * *} \\
0.363^{* * *}\end{array}$ & $\begin{array}{l}(0.006) \\
(0.035)\end{array}$ & $\begin{array}{l}0.036^{* * *} \\
0.376^{* * *}\end{array}$ & $\begin{array}{l}(0.006) \\
(0.035)\end{array}$ \\
\hline $\begin{array}{l}\text { Branding Capital } \\
\text { Marketing } \\
\text { Trademark Stock }\end{array}$ & & & $\begin{array}{l}0.026^{* * *} \\
0.028^{* * *}\end{array}$ & $\begin{array}{l}(0.004) \\
(0.006)\end{array}$ & $\begin{array}{l}0.020^{* * *} \\
0.029 * * *\end{array}$ & $\begin{array}{l}(0.004) \\
(0.006)\end{array}$ \\
\hline $\begin{array}{l}\text { Controls } \\
\text { East Germany } \\
\text { Group } \\
\text { Export }\end{array}$ & $\begin{array}{r}-0.152^{* * *} \\
0.138^{* * *} \\
0.173^{* * *}\end{array}$ & $\begin{array}{l}(0.012) \\
(0.015) \\
(0.030)\end{array}$ & $\begin{array}{l}-0.013 \\
-0.027^{* *} \\
-0.054^{* *}\end{array}$ & $\begin{array}{l}(0.012) \\
(0.013) \\
(0.026)\end{array}$ & $\begin{array}{l}-0.016 \\
-0.027^{* *} \\
-0.052^{* *}\end{array}$ & $\begin{array}{l}(0.012) \\
(0.013) \\
(0.026)\end{array}$ \\
\hline $\begin{array}{l}\text { W_Time } \\
\text { W_Industry } \\
\text { Adjusted R2 } \\
\text { Observations }\end{array}$ & $\begin{array}{l}0.013 \\
0.000 \\
0.725 \\
6,878\end{array}$ & & $\begin{array}{l}0.000 \\
0.000 \\
0.053 \\
6,878\end{array}$ & & $\begin{array}{l}0.333 \\
0.000 \\
0.049 \\
6,878\end{array}$ & \\
\hline
\end{tabular}

Notes: Significance levels: ${ }^{* * *} \mathrm{p}<0.01,{ }^{* *} \mathrm{p}<0.05,{ }^{*} \mathrm{p}<0.1$. Standard errors in parentheses. Estimation method: Olley and Pakes (1996). The number of observations refers to the first stage regression. Regression additionally includes six dummies indicating R\&D, Design \& Licenses, Training, Marketing, and Trademark Stock is zero.

Table 8 compares estimation results using PIM capital stocks (Column 1) with results for intangibles proxied by expenses (Column 2). PIM capital stocks are calculated for R\&D, Design \& Licenses, Training, and Marketing. Overall, results are very similar in both regressions. For the reduced subsample, we still find HC and $\mathrm{BC}$ to be productivity enhancing. In contrast R\&D and Design \& Licenses are not significant using expenditures but R\&D becomes significant again in the PIM-version. Both are estimated by a subsample of 6,876 observations.

The results show that expenses qualify as proxies for capital stocks from our theoretical considerations as well as from the empirical results presented above.

\subsection{The Role of Organizational Investment on Productivity}

Our estimates so far might have neglected an other important type of intangible assets: Organizational Capital. As explained in section 4 it is still a difficult task to 
measure organizational capital and we consider the introduction of an organizational innovation as an improvement in Organizational Capital. We extend equation 7 by including three dummy variables indicating organizational innovation in business practices, workplace organization and external relationships.

Table 9: Effect of Organizational Investment on Firm-Level Productivity

\begin{tabular}{|c|c|c|c|c|c|c|c|c|}
\hline & $\begin{array}{l}(1) \\
1 \mathrm{st}\end{array}$ & $\begin{array}{l}(2) \\
\text { 2nd }\end{array}$ & $\begin{array}{l}(3) \\
\text { 2nd }\end{array}$ & $\begin{array}{l}(4) \\
\text { 2nd }\end{array}$ & $\begin{array}{l}(5) \\
\text { 2nd }\end{array}$ & $\begin{array}{l}(6) \\
\text { 2nd }\end{array}$ & $\begin{array}{l}(7) \\
\text { 2nd }\end{array}$ & $\begin{array}{l}(8) \\
\text { 2nd }\end{array}$ \\
\hline Capital & $\begin{array}{l}0.133^{* * *} \\
(0.029)\end{array}$ & & & & & & & \\
\hline Labour & $\begin{array}{c}-0.013^{* * *} \\
(0.005)\end{array}$ & & & & & & & \\
\hline Material & $\begin{array}{l}0.382^{\text {*** }} \\
(0.008)\end{array}$ & & & & & & & \\
\hline \multicolumn{9}{|l|}{ Organizational Capital } \\
\hline Business Process & & $\begin{array}{l}0.050^{* * *} \\
(0.014)\end{array}$ & $\begin{array}{c}* 0.033^{* *} \\
(0.014)\end{array}$ & $\begin{array}{c}0.027^{* *} \\
(0.014)\end{array}$ & $\begin{array}{l}0.038^{* * *} \\
(0.014)\end{array}$ & $\begin{array}{c}* 0.022 \\
(0.014)\end{array}$ & $\begin{array}{c}0.026^{*} \\
(0.014)\end{array}$ & $\begin{array}{c}0.026^{*} \\
(0.014)\end{array}$ \\
\hline Labour Organization & & $\begin{array}{c}-0.018 \\
(0.014)\end{array}$ & $\begin{array}{c}-0.020 \\
(0.014)\end{array}$ & $\begin{array}{c}-0.020 \\
(0.014)\end{array}$ & $\begin{array}{c}-0.017 \\
(0.014)\end{array}$ & $\begin{array}{c}-0.017 \\
(0.014)\end{array}$ & $\begin{array}{c}-0.027^{*} \\
(0.014)\end{array}$ & $\begin{array}{c}-0.026^{*} \\
(0.014)\end{array}$ \\
\hline Relation Management & & $\begin{array}{c}0.028^{*} \\
(0.015)\end{array}$ & $\begin{array}{c}0.004 \\
(0.015)\end{array}$ & $\begin{array}{c}0.006 \\
(0.014)\end{array}$ & $\begin{array}{c}0.002 \\
(0.015)\end{array}$ & $\begin{array}{c}-0.013 \\
(0.014)\end{array}$ & $\begin{array}{c}0.009 \\
(0.015)\end{array}$ & $\begin{array}{c}-0.008 \\
(0.015)\end{array}$ \\
\hline \multicolumn{9}{|l|}{ Innovative Capital } \\
\hline $\mathrm{R} \& \mathrm{D}$ & & & $\begin{array}{l}0.059^{* * *} \\
(0.006)\end{array}$ & & & $\begin{array}{l}0.034^{* *}= \\
(0.006)\end{array}$ & $\begin{array}{c}* 0.063^{* * *} \\
(0.015)\end{array}$ & $\begin{array}{c}0.045^{* * *} \\
(0.017)\end{array}$ \\
\hline Design \& Licenses & & & $\begin{array}{l}0.013^{* * *} \\
(0.003)\end{array}$ & & & $\begin{array}{l}0.008^{* *} \\
(0.003)\end{array}$ & $* \begin{array}{c}0.005 \\
(0.013)\end{array}$ & $\begin{array}{l}0.046^{* * *} \\
(0.016)\end{array}$ \\
\hline Patent Stock & & & $\begin{array}{c}0.010 \\
(0.007)\end{array}$ & & & $\begin{array}{c}0.001 \\
(0.007) \\
\end{array}$ & $\begin{array}{l}0.069^{* * * *} \\
(0.023)\end{array}$ & $\begin{array}{c}0.029 \\
(0.023) \\
\end{array}$ \\
\hline \multicolumn{9}{|l|}{ Human Capital } \\
\hline Training & & & & $\begin{array}{l}0.060^{* * *} \\
(0.005)\end{array}$ & & $\begin{array}{l}0.032^{* *}= \\
(0.006)\end{array}$ & $\begin{array}{c}* 0.051^{* * *} \\
(0.019)\end{array}$ & $\begin{array}{c}0.095^{* * *} \\
(0.013)\end{array}$ \\
\hline High Skilled Labour & & & & $\begin{array}{l}0.347^{* * *} \\
(0.031)\end{array}$ & & $\begin{array}{l}0.255^{* *} \\
(0.032)\end{array}$ & $\begin{array}{c}* 0.094^{* * * *} \\
(0.019)\end{array}$ & $\begin{array}{c}0.119 * * * \\
(0.013)\end{array}$ \\
\hline \multicolumn{9}{|l|}{ Branding Capital } \\
\hline Marketing & & & & & $\begin{array}{l}0.068^{* * *} \\
(0.004)\end{array}$ & $\begin{array}{c}* 0.047^{* * *} \\
(0.005)\end{array}$ & $* \begin{array}{c}0.010 \\
(0.016)\end{array}$ & $\begin{array}{l}0.102^{* * *} \\
(0.013)\end{array}$ \\
\hline Trademark Stock & & & & & $\begin{array}{l}0.018^{* * *} \\
(0.006)\end{array}$ & $* \begin{array}{c}0.008 \\
(0.006)\end{array}$ & $\begin{array}{l}0.068^{* * *} \\
(0.014)\end{array}$ & $\begin{array}{l}0.059^{* * * *} \\
(0.016)\end{array}$ \\
\hline \multicolumn{9}{|l|}{ Controls } \\
\hline East Germany & $\begin{array}{c}-0.163^{* * *} \\
(0.012)\end{array}$ & $\begin{array}{c}0.001 \\
(0.012)\end{array}$ & $\begin{array}{c}-0.010 \\
(0.012)\end{array}$ & $\begin{array}{c}-0.014 \\
(0.012)\end{array}$ & $\begin{array}{c}0.020 \\
(0.012)\end{array}$ & $\begin{array}{c}-0.004 \\
(0.012)\end{array}$ & $\begin{array}{c}0.003 \\
(0.012)\end{array}$ & $\begin{array}{c}-0.008 \\
(0.012)\end{array}$ \\
\hline Group & $\begin{array}{l}0.148^{* * *} \\
(0.015)\end{array}$ & $\begin{array}{r}{ }^{*}-0.013 \\
(0.013)\end{array}$ & $\begin{array}{c}-0.017 \\
(0.013)\end{array}$ & $\begin{array}{c}-0.025^{* *} \\
(0.013)\end{array}$ & $\begin{array}{c}-0.025^{*} \\
(0.013)\end{array}$ & $\begin{array}{c}-0.033^{* *} \\
(0.013)\end{array}$ & $\begin{array}{c}-0.048^{* * *} \\
(0.013)\end{array}$ & $\begin{array}{c}* 0.036^{* * *} \\
(0.013)\end{array}$ \\
\hline Export & $\begin{array}{l}0.146^{* * * *} \\
(0.025)\end{array}$ & $\begin{array}{c}0.001 \\
(0.023) \\
\end{array}$ & $\begin{array}{c}-0.061^{* * *} \\
(0.023)\end{array}$ & $\begin{array}{c}* 0.034 \\
(0.022) \\
\end{array}$ & $\begin{array}{c}-0.044^{*} \\
(0.023) \\
\end{array}$ & $\begin{array}{c}-0.080^{* *}= \\
(0.023)\end{array}$ & $\begin{array}{c}* 0.051^{* *} \\
(0.023) \\
\end{array}$ & $\begin{array}{c}-0.058^{* *} \\
(0.023) \\
\end{array}$ \\
\hline W_Time & 0.168 & 0.875 & 0.751 & 0.857 & 0.449 & 0.401 & 0.766 & 0.765 \\
\hline W_Industry & 0.000 & 0.889 & 0.000 & 0.000 & 0.000 & 0.000 & 0.045 & 0.000 \\
\hline Adjusted R⿳⺈ & 0.693 & 0.001 & 0.028 & 0.043 & 0.043 & 0.070 & 0.018 & 0.050 \\
\hline Observations & 7,543 & 7,543 & 7,543 & 7,543 & 7,543 & 7,543 & 7,543 & 7,543 \\
\hline
\end{tabular}

Notes: Significance levels: $* * * \mathrm{p}<0.01, * * \mathrm{p}<0.05, * \mathrm{p}<0.1$. Standard errors in parentheses. Estimation method: Olley and Pakes (1996). The number of observations refers to the first stage regression in OP. Due to the time structure 5,132 observations remain in the non-linear regression of the second stage. Regression additionally includes six dummies indicating R\&D, Design \& Licenses, Firm-specific Training, Marketing, and Trademark Stock is zero. In Column (7) and (8) Innovative, Human, and Branding Capital is measured by dummy variables: Column (7): Each component of IC, HC, BC is measured by a dummy variable which is 1 for positive expenditures. Column (8): Like Column (7) but dummy is 1 for expenditures larger than the median.

Table 9 illustrates the effects of organizational capital on productivity. In Columns (2) to (5), we explore the role of organizational capital on productivity when we stepwise include other types of intangible assets. Column (6) presents the full model 
specification. Overall, the results for Organizational Capital are mixed. Innovations in firms' business processes and external relations turn out to be significant in (2) when we do not account for other intangible assets. However, these productivity effects get smaller when we account for additional intangible assets and they even vanish in the full model specification (6). Whereas the productivity stimulus of traditional input factors and intangibles assets (with the exception of patents and trademarks) remains positive and significant, the different types of organizational innovations seems to have no significant impact on labour productivity.

One explanation why we find significant effects for R\&D, Human and Branding Capital but not for Organizational Capital might be rooted in the fact that the first ones are quantitative measures whereas Organizational Capital is a dummy variable. We therefore dig deeper and check robustness of our results by measuring innovative, human and branding capital using dummy variables that equal 1 if the corresponding expenditure or stock is positive and zero else (Column 7). These indicator variables incorporate less information thus it is maybe not surprising that we do not find any effect for Design \& Licenses and Marketing due to the limited information content of these variables. On the contrary, the effects of R\&D, Patents, Human Capital and Trademarks survive even using indicator variables. In contrast to Column (6), Organizational Capital matters in Column (7). We find improvements in business processes to foster productivity whereas changes in workplace organization lead on average to a decline in productivity (at least in the short-run). As an alternative Column (8) employs indicator variables for Innovative, Human and Branding Capital which take the value one if the firm invests a disproportionate high share in these intangibles above the median. The results are provided in column (8). Unlike in Column (7), the results confirm strong productivity enhancing effects for all proxies for Innovative, Human and Branding Capital and thus corroborate findings from our main regression in Table 4 . But we still yield the same mixed results for Organizational Capital.

\subsection{Complementarity Between Intangible Assets}

Finally, we are interested in the question whether complementary or substitutive relations between various components of Innovative Capital, Human Capital, and Branding Capital exist. Complementarity (substitutability) between two intangibles is defined as an increase (decrease) in total factor productivity of one intangible asset through the investment in another intangible.

Since we have multiple components of intangible assets which are quantitative in nature, we follow a recent methodology by Carree et al. (2011) to test whether complementarity or substitutability exist. They emphasize that with more than two practices, estimates of only pair-wise interaction effects are potentially biased, since the joint investment in several intangibles might affect marginal productiv- 
ity as well. Their approach considers, in consequence, the impact of all additional cross-terms. Starting point of their test procedure is the objective function $f\left(x_{1}, x_{2}, x_{3}, x_{4}, x_{5}, x_{6}, x_{7}\right)$ which includes all combinations of cross-terms of intangible components $x_{1}$ to $x_{7}$. The test indicates complementarity of two components $\left(x_{1}\right.$ and $\left.x_{2}\right)$ if the cross derivative of the objective function is non-negative $\left(\partial^{2} f / \partial x_{1} \partial x_{2} \geq 0\right)$ for all values $\left(x_{1}, x_{2}, x_{3}, x_{4}, x_{5}, x_{6}, x_{7}\right)$ with the inequality being strictly positive for at least one value. The definition for substitutability applies accordingly; the cross derivatives have to be non-positive with at least one strictly negative.

The cross-derivatives constitute the hypotheses, that are tested simultaneously. In our case of seven components of intangible capital, the number of hypotheses is 32 . The objective function is rewritten according to the hypotheses (see Table 8.D.1 in the appendix) and all separate hypotheses are tested simultaneously using linear regression. The combined hypothesis of complementarity or substitutability is accepted if all the separate hypotheses are accepted. Carree et al. (2011) show that in this setting the test indicates complementarity between two components, if the coefficient for at least one of the 32 variables representing the hypotheses is positive and significant while none of the coefficients of the other variables (hypotheses) is significantly negative and vice versa for substitutability. Since we have multiple restrictions, the significance level of the combined hypotheses is adjusted by the Bonferroni and alternatively by the Sidak procedure.

The seven components of intangible assets allow for 21 pair-wise combinations that are tested for complementarity or substitutability relations. Table 10 provides results only for those three combinations that turn out to be significant. The results show some interesting relationships between different kind of intangible assets. We find two components of Innovative Capital, R\&D and Patent Stock, to be complements. $R \& D$ is proxied by current expenses and indicates a firm's innovation input, while the Patent Stock captures the firm's whole patenting history and the (patentable) output of its innovation activities. The complementarity of these two components indicate that marginal productivity of $R \& D$ increases if the Patent Stock increases. This points to the importance of a stock of prior knowledge as basis for a learning effect. Prior knowledge leads also to the creation of "absorptive capacity" (Cohen and Levin, 1989), which makes investments in a firm's research and development activities more productive.

The results furthermore show innovative capital and human capital on the one hand and innovative capital and branding capital on the other hand to be complements with respect to productivity. To be more precise, the patent stock and skilled labour are complementary, suggesting that a firm's human capital is a key asset to make commercial use of the patented technological knowledge more productive. We also find patents and marketing to be complements, that is the marginal return of the technological knowledge, captured by the patent stock, increases, as the marketing 
Table 10: Complementarities and Substitutabilities

\begin{tabular}{|c|c|c|c|}
\hline & $(1)$ & $(2)$ & (3) \\
\hline Test & $\mathrm{R} \& \mathrm{D} \times$ Patents & Patents $\times$ Skilled Labour & Patents $\times$ Marketing \\
\hline H1 & . & . & . \\
\hline $\mathrm{H} 2$ & . & . & . \\
\hline H3 & 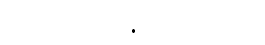 & . & . \\
\hline $\mathrm{H} 4$ & $(+++)$ & . & $(++)$ \\
\hline H5 & . & . & . \\
\hline $\mathrm{H} 6$ & . & . & . \\
\hline $\mathrm{H} 7$ & . & . & . \\
\hline $\mathrm{H} 8$ & $(+++)$ & & $(+)$ \\
\hline H9 & . & $(+)$ & . \\
\hline H10 & . & . & . \\
\hline H11 & $(++)$ & . & $(++)$ \\
\hline H12 & . & . & . \\
\hline H13 & . & . & . \\
\hline H14 & . & . & $(++)$ \\
\hline H15 & $(+++)$ & . & $(++)$ \\
\hline H16 & . & . & . \\
\hline H17 & $(++)$ & . & $(++)$ \\
\hline H18 & . & . & . \\
\hline H19 & . & . & . \\
\hline $\mathrm{H} 20$ & - & $(+)$ & . \\
\hline $\mathrm{H} 21$ & $(+++)$ & . & . \\
\hline $\mathrm{H} 22$ & . & . & . \\
\hline $\mathrm{H} 23$ & 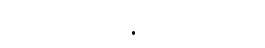 & . & $(++)$ \\
\hline $\mathrm{H} 24$ & $(++)$ & . & $(++)$ \\
\hline $\mathrm{H} 25$ & . & . & . \\
\hline $\mathrm{H} 26$ & . & . & $(+)$ \\
\hline $\mathrm{H} 27$ & . & . & $(+)$ \\
\hline $\mathrm{H} 28$ & $(++)$ & . & $(+)$ \\
\hline $\mathrm{H} 29$ & . & . & . \\
\hline $\mathrm{H} 30$ & . & . & . \\
\hline H31 & . & . & $(++)$ \\
\hline H32 & 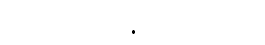 & . & . \\
\hline
\end{tabular}

Notes: Estimation method: Olley and Pakes (1996). Bonferroni-corrected significance levels of complements: $(+++) \mathrm{p}<0.01,(++) \mathrm{p}<0.05,(+)$ $\mathrm{p}<0.1$. Significance levels of substitutes: $(---) \mathrm{p}<0.01,(--) \mathrm{p}<0.05$, $(-) \mathrm{p}<0.1$. Both corrections (Bonferroni and Sidak) lead to nearly identical results. A more detailed presentation of the hypotheses is provided in the Appendix section 8.D. Detailed regression results are available on request.

intensity increases. This finding stresses the importance of a firm's ability to successfully market innovative products, in addition to its ability to develop the technological basis for these products in the first place. Marketing enhance the commercial success because it helps to increase the awareness of potential customers. Marketing activities also influence the perception of desirable overall quality, and address favorable associations (Keller and Lehmann, 2006). Reciprocally, the patent stock might add to a firm's reputation and thus enhance the marginal return of marketing. 


\section{Conclusion}

In contrast to many recent papers investigating the contribution of intangible assets to productivity growth at the macro level, this paper takes a firm-level perspective. It contributes to the literature by simultaneously investigating productivity effects of a comprehensive set of intangible assets following to a large extent the conceptual framework of Corrado et al. (2009). To the best of our knowledge, this paper is furthermore the first to investigate for a large set of intangibles whether they are complements or substitutes. In particular, our econometric approach accounts for Innovative Capital (measured by current R\&D expenditure, design \& licenses expenditure, and patent stock), Human Capital (proxied by training expenditure and share of high skilled labour), Branding Capital (measured by marketing expenditure and trademark stocks), and Organizational Capital (proxied by the introduction of different kinds of organizational innovations).

Table 11: Complementarity and Substitutability Between Intangibles

\begin{tabular}{|c|c|c|c|c|c|c|c|}
\hline & $\mathrm{R} \& \mathrm{D}$ & Design & Patent & Training & Skilled & Marketing & Trademark \\
\hline $\mathrm{R} \& \mathrm{D}$ & & & complement & & & & \\
\hline \multicolumn{8}{|l|}{ Design } \\
\hline Patent & complement & & & & complement & complement & \\
\hline \multicolumn{8}{|l|}{ Training } \\
\hline Skilled & & & complement & & & & \\
\hline Marketing & & & complement & & & & \\
\hline Trademark & & & & & & & \\
\hline
\end{tabular}

Using panel data for German companies covering the period 2006-2010, we can draw the following conclusions. First, even when controlling for a comprehensive set of intangible assets, we find strong productivity-enhancing effects for R\&D, Brand Capital and Human Capital. However, due to collinearity the single effects turn out to be smaller compared to studies that use one type of intangible assets only. Interestingly, the short-run productivity effect of an increase in training expenditure is stronger than for $R \& D$ expenditure or marketing expenditure which are of similar size. Second, we also find slightly positive long-term productivity effects for firms investing in innovative capital and branding capital. That is both a firm's accumulated stock of granted patents and trademarks are conducive to current pro- 
ductivity. Third, our findings suggest that not only R\&D is productivity-enhancing. Firms that increase their expenditure for design and licenses also experienced productivity gains though the effect is rather small in magnitude. Fourth, results for Organizational Capital turn out to be mixed. We find a productivity enhancing effect for firms investing in organizational capital by changing business processes. However, the opposite holds when firms introduce new workplace organizations.

Fifth, our studies also show some interesting complementarities between different kinds of intangible assets. We find R\&D and patent stocks to be complementary, pointing to the importance of prior knowledge and the creation of absorptive capacity. Furthermore, the results show innovative capital and human capital on the one hand and innovative capital and branding capital on the other hand to be complements with respect to productivity. We find in particular that the patent stock and skilled labour are complements as well as the patent stock and marketing. And finally, our results are robust to different parametric and non-parametric production function estimates accounting for selectivity and endogeneity, as well as different kinds of measurement of productivity and intangible capital. 


\section{References}

Abramovsky, L. and Griffith, R. (2009), ICT, Corporate Restructuring and Productivity, Institute for Fiscal Studies Working Papers W09/10.

Aschhoff, B., Baier, E., Crass, D., Hud, M., Hünermund, P., Köhler, C., Peters, B., Rammer, C., Schricke, E., Schubert, T. et al. (2013), Innovation in Germany - Results of the German CIS 2006 to 2010. Background report on the Innovation Surveys 2007, 2009 and 2011 of the Mannheim Innovation Panel, Zew-dokumentation 13-01, Mannheim.

Ballot, G., Fakhfakh, F. and Taymaz, E. (2006), 'Who Benefits from Training and R\&D, the Firm or the Workers?', British Journal of Industrial Relations 44(3), 473-495.

Bertschek, I. (2003), 'Information technology and productivity gains and cost savings in companies', New Economy Handbook, Elsevier Science, Amsterdam pp. 213228.

Bertschek, I. and Kaiser, U. (2004), 'Productivity Effects of Organizational Change: Microeconometric Evidence', Management Science, INFORMS 50(3), 394-404.

Black, S. E. and Lynch, L. (1996), 'Human-Capital Investments and Productivity', American Economic Review 86(2), 263-267.

Black, S. E. and Lynch, L. M. (2001), 'How To Compete: The Impact Of Workplace Practices And Information Technology On Productivity', The Review of Economics and Statistics 83(3), 434-445.

Bloom, N., Sadun, R. and van Reenen, J. (2010), 'Recent Advances in the Empirics of Organizational Economics', Annual Review of Economics 2(1), 105-137.

Bloom, N., Sadun, R. and van Reenen, J. (2012), 'The Organization of Firms Across Countries', The Quarterly Journal of Economics 127(4), 1663-1705.

Bloom, N. and van Reenen, J. (2007), 'Measuring and Explaining Management Practices Across Firms and Countries', Quarterly Journal of Economics 122(4), 13411408.

Bontempi, M. E. and Mairesse, J. (2014), 'Intangible Capital and Productivity at the Firm Level: A Panel Data Assessment', Economics of Innovation and New Technology (ahead-of-print), 1-30.

Bresnahan, T. F. (2002), Prospects for an Information-Technology-Led Productivity Surge, in 'Innovation Policy and the Economy, Volume 2', NBER Chapters, National Bureau of Economic Research, Inc, pp. 135-162. 
Brynjolfsson, E. and Hitt, L. (1996), 'Paradox Lost? Firm-Level Evidence on the Returns to Information Systems Spending', Management Science 42(4), 541-558.

Brynjolfsson, E. and Hitt, L. M. (2003), 'Computing Productivity: Firm-Level Evidence', Review of Economics and Statistics 85(4), 793-808.

Carree, M., Lokshin, B. and Belderbos, R. (2011), 'A note on testing for complementarity and substitutability in the case of multiple practices', Journal of Productivity Analysis 35(3), 263-269.

Cohen, W. M. and Levin, R. C. (1989), Empirical Studies of Innovation and Market Structure, in R. M. A. Schmalensee and R. D. Willig, eds, 'Handbook of Industrial Organization', Vol. 2, Elsevier, pp. 1059-1107.

Corrado, C., Hulten, C. and Sichel, D. (2009), 'Intangible capital and economic growth', The Review of Income and Wealth 55(3), 661-685.

Crass, D., Licht, G. and Peters, B. (2015), Intangible Assets and Investments at the Sector Level - Empirical Evidence for Germany, in A. Bonfour and T. Miyagawa, eds, 'Intangibles, Market Failure and Innovation Performance', Springer.

Crass, D., Licht, G., Peters, B. and Sofka, W. (2009), Time Series Estimates of Intangible Investments - Sensitivity Analysis for Germany, Technical report, ZEW, Mannheim.

URL: www.coinvest.org.uk/bin/view/CoInvest/CoinvestPub

Crépon, B., Duguet, E. and Mairesse, J. (1998), 'Research, Innovation and Productivity: An Econometric Analysis at the Firm Level', Economics of Innovation and New Technology 7(2), 115-158.

de la Fuente, A. (2011), Human capital and productivity, Barcelona Working paper 530, Barcelona.

Dearden, L., H., R. and van Reenen, J. (2006), 'The Impact of Training on Productivity and Wages: Evidence from British Panel Data', Oxford Bulletin of Economics \& Statistics 68, 397-421.

Doms, M. and Bartelsman, E. J. (2000), 'Understanding Productivity: Lessons from Longitudinal Microdata', Journal of Economic Literature 38(3), 569-594.

Doraszelski, U. and Jaumandreu, J. (2014), Measuring the Bias of Technological Change, mimeo.

Draca, M., Sadun, R. and van Reenen, J. (2007), 'ICT and Productivity: A Review of the Evidence', Handbook of Information and Communication Technologies . 
Eberhardt, M. and Helmers, C. (2010), Untested Assumptions and Data Slicing: A Critical Review of Firm-Level Production Function Estimators, Economics Series Working Papers 513, University of Oxford, Department of Economics.

Economides, N. (1998), 'Trademarks', The New Palgrave Dictionary of Economics and the Law (Peter Newman, Ed.).

Greenhalgh, C. and Longland, M. (2005), 'Running to Stand Still? - The Value of R\&D, Patents and Trade Marks in Innovating Manufacturing Firms', International Journal of the Economics of Business 12(3), 307-328.

Greenhalgh, C. and Rogers, M. (2012), 'Trade Marks and Performance in Services and Manufacturing Firms: Evidence of Schumpeterian Competition through Innovation', Australian Economic Review 45(1), 50-76.

Griliches, Z. (1979), 'Issues in Assessing the Contribution of Research and Development to Productivity Growth', The Bell Journal of Economics 10(1), 92-116.

Grimes, A., Ren, C. and Stevens, P. (2012), 'The Need for Speed: Impacts of Internet Connectivity on Firm Productivity', Journal of Productivity Analysis $\mathbf{3 7}(2), 187-201$.

Hall, B. H., Mairesse, J. and Mohnen, P. (2010), Measuring the Returns to R\&D, in B. H. Hall and N. Rosenberg, eds, 'Handbook of the Economics of Innovation', Vol. 2, Elsevier, chapter 22, pp. 1033-1082.

Hall, B. and Mairesse, J. (2006), 'Empirical studies of innovation in the knowledgedriven economy', Economics of Innovation and New Technology 15(4-5), 289-299.

Hao, J., Manole, V. and van Ark, B. (2009), Intangible Capital and Growth - an International Comparison, Coinvest deliverable d3.6: Paper quantifying figures on time-series estimates dating back to 1980, Brussels.

URL: www.coinvest.org.uk/bin/view/CoInvest/CoinvestPub

Hempell, T. (2005), 'WhatŠs Spurious, What ̌̌s Real? Measuring the Productivity Impacts of ICT at the Firm-Level.', Empirical Economics 30(2), 427-464.

Keller, K. L. and Lehmann, D. R. (2006), 'Brands and Branding: Research Findings and Future Priorities', Marketing Science 25(6), 740-759.

Konings, J. and Vanormelingen, S. (2009), The Impact of Training on Productivity and Wages: Firm Level Evidence, C.E.P.R. Discussion Papers 7473, London.

Kretschmer, T., Cardona, M. and Strobel, T. (2013), 'The Contribution of ICT to Productivity: Key Conclusions from Surveying the Empirical Literature', Information Economics and Policy 3(25), 109-125. 
Levinsohn, J. and Petrin, A. (2003), 'Estimating Production Functions Using Inputs to Control for Unobservables', Review of Economic Studies 70(2), 317-341.

Mairesse, J. and Sassenou, M. (1991), R\&D Productivity: A Survey of Econometric Studies at the Firm Level, NBER Working Papers 3666, Cambridge, MA.

Marrano, G. and Haskel, J. (2007), How Much Does the UK Invest in Intangible Assets?, C.E.P.R Discussion Papers 6287, London.

Marrocu, E., Paci, R. and Pontis, M. (2012), 'Intangible capital and firms' productivity', Industrial and Corporate Change 21(2), 377-402.

Marschak, J. and Andrews, W. H. (1944), 'Random Simultaneous Equations and the Theory of Production', Econometrica 12(3), 143-205.

Olley, G. S. and Pakes, A. (1996), 'The Dynamics of Productivity in the Telecommunications Equipment Industry', Econometrica 64(6), 1263-1297.

Peters, B. (2008), Innovation and Firm Performance - An Empirical Investigation for German Firms, ZEW Economic Studies 38, Heidelberg, New York.

Peters, B. and Rammer, C. (2013), Innovation panel surveys in Germany, in F. Gault, ed., 'Handbook of Innovation Indicators and Measurement', Edward Elgar Publishing, Cheltenham, UK and Northampton, MA, USA, chapter 6, pp. $135-177$.

Polder, M., van Leeuwen, G., Mohnen, P. and Raymond, W. (2009), Productivity effects of innovation modes, Discussion paper 09033, Statistics Netherlands, Den Haag.

Ramirez, P. and Hachiya, T. (2008), 'A comprehensive study on profits and sustainable competitive advantages', Management Research News 31(9), 670-682.

Sarbu, M. (2013), Does Social Software Increase Labour Productivity?, ZEW Discussion Papers 13-041.

Solow, R. M. (1987), 'We'd better watch out', New York Times Book Review p. 36.

Syverson, C. (2011), 'What Determines Productivity?', Journal of Economic Literature 49(2), 326-365. 


\section{Appendix}

\section{A Definition of Variables}

Table 12: Description and Definition of Main Variables

\begin{tabular}{|c|c|c|}
\hline Variable & Model & Description \\
\hline Labour Productivity & $\mathbf{Q} / \mathbf{L}$ & Turnover per employee in year $t$, in logs. \\
\hline Total Factor Productivity & TFP & TFP is computed based on equation 6 . \\
\hline Value Added & VA & $\begin{array}{l}\text { Difference between turnover and expenses for materials per } \\
\text { employee in year } t \text {, in logs. }\end{array}$ \\
\hline Capital & $\mathbf{K}$ & $\begin{array}{l}\text { Physical capital stock (in book values) per employee in year } \\
\mathrm{t} \text {, in logs. Capital is updated by investments and a industry } \\
\text { specific depreciation rate. Book value and investments are } \\
\text { based on direct survey information. }\end{array}$ \\
\hline Labour & $\mathbf{L}$ & $\begin{array}{l}\text { Log number of employees in year } \mathrm{t} \text { (annual averages; incl } \\
\text { apprentices and interns; without R\&D employees). }\end{array}$ \\
\hline Material & $\mathbf{M}$ & $\begin{array}{l}\text { Expenses for materials, intermediate inputs, and energy (incl. } \\
\text { ordered services) per employee in year t, in logs. }\end{array}$ \\
\hline Innovative Capital & IC & \\
\hline $\mathrm{R} \& \mathrm{D}$ & RD & $\begin{array}{l}R \& D \text { expenditures per employee in year } t, \text { in logs. } R \& D \text { in } \\
\text { cludes in-house } R \& D \text { and external } R \& D(R \& D \text { contracted out } \\
\text { to third parties). }\end{array}$ \\
\hline Design \& Licenses & DL & $\begin{array}{l}\text { Expenses for design, licenses and other external knowledge } \\
\text { and product preparation related to innovation per employee } \\
\text { in year t; in logs. }\end{array}$ \\
\hline Patent Stock & $\mathbf{P}$ & $\begin{array}{l}\text { Stock of granted patents at the European Patent Office in year } \\
\mathrm{t}-1 \text {, in logs. A depreciation rate of } 15 \% \text { is applied. }\end{array}$ \\
\hline Human Capital & $\mathrm{HC}$ & \\
\hline Training & $\mathbf{T}$ & $\begin{array}{l}\text { Expenditures for professional development training (internal } \\
\text { and external per employee in year } t \text {, in logs. }\end{array}$ \\
\hline High Skilled Labour & SL & Share of employees holding a university or college degree. \\
\hline Branding Capital & $\mathbf{B C}$ & \\
\hline Marketing & $\mathbf{M}$ & $\begin{array}{l}\text { Marketing expenditures per employee in year t, in logs. In- } \\
\text { cludes all internal and external expenditures for advertise- } \\
\text { ment, for the conceptual design of marketing strategies, mar- } \\
\text { ket and costumer research, and the installation of new distri- } \\
\text { bution channels, without market expenditures for innovation } \\
\text { projects. }\end{array}$ \\
\hline Trademark Stock & $\mathbf{T M}$ & $\begin{array}{l}\text { Stock of registered trademarks at the German Patent and } \\
\text { Trademark Office (DPMA) and the Office for Harmonisation } \\
\text { in the Internal Market (OHIM) without depreciation per em- } \\
\text { ployee in year t-1, in logs. }\end{array}$ \\
\hline Organisational Capital & $\mathrm{OC}$ & \\
\hline Business Processes & BP & $\begin{array}{l}\text { Organizational investment in business processes (e.g. intro- } \\
\text { duction of quality management systems, supply chain manage- } \\
\text { ment systems, lean production, matrix organization, knowl- } \\
\text { edge management) in the period } t-2 \text { to } t \text {. }\end{array}$ \\
\hline Labour Organization & LO & $\begin{array}{l}\text { Organizational investment in labour organization (e.g. decen- } \\
\text { tralization or centralization of decision making, job rotation, } \\
\text { team work, basic realignment of departments) in the period } \\
t-2 \text { to } t \text {. }\end{array}$ \\
\hline Relation Management & RM & $\begin{array}{l}\text { Organizational investment in external relations (e.g. alliances, } \\
\text { cooperation agreements, outsourcing, customer relationship, } \\
\text { supplier integration) in the period } t-2 \text { to } t \text {. }\end{array}$ \\
\hline \multicolumn{3}{|l|}{ Control Variables } \\
\hline Industry & $\mathbf{I}$ & Set of 25 industry dummies. \\
\hline Export intensity & EX & Share of exports in turnover in year t $(0 / 1)$. \\
\hline East Germany & $\mathbf{E}$ & Headquarter in East Germany in year t $(0 / 1)$. \\
\hline Group & $\mathbf{G}$ & Company is part of a group in year t $(0 / 1)$. \\
\hline
\end{tabular}




\section{B Depreciation and Growth Rates}

Table 13: Depreciation- and Growth Rates for Intangibles

\begin{tabular}{lcc}
\hline & $\begin{array}{c}\text { Growth rate } \\
\text { (in \%) }\end{array}$ & $\begin{array}{c}\text { Depreciation } \\
\text { rate (in \%) }\end{array}$ \\
\hline R\&D & 2.48 & 20.00 \\
Design \& Licenses & 2.48 & 20.00 \\
Marketing & -0.55 & 60.00 \\
Training & 0.03 & 40.00 \\
\hline
\end{tabular}

Notes: Growth rates are based on time series of intangibles for Germany for the time period 1995-2006 (Crass et al., 2015). Depreciation rates have been taken from Corrado et al. (2009).

\section{C Correlation Matrix}

Table 14: Correlation Coefficients of Intangibles (Dummy-Variables)

\begin{tabular}{|c|c|c|c|c|c|c|c|c|c|c|}
\hline & $\mathrm{RD}$ & $\mathrm{DL}$ & $\mathrm{P}$ & $\mathrm{T}$ & $\mathrm{SL}$ & $\mathrm{M}$ & $\mathrm{TM}$ & $\mathrm{BP}$ & LO & $\mathrm{RM}$ \\
\hline $\mathrm{RD}$ & \multicolumn{10}{|c|}{1.00} \\
\hline DL & \multicolumn{10}{|c|}{$0.37^{* * *} 1.00$} \\
\hline $\mathrm{P}$ & \multicolumn{10}{|c|}{$0.36^{* * *} 0.17^{* * *} 1.00$} \\
\hline $\mathrm{T}$ & \multicolumn{10}{|c|}{$0.19^{* * *} 0.16^{* * *} 0.11^{* * *} 1.00$} \\
\hline SL & \multicolumn{10}{|c|}{$0.22^{* * *} 0.14^{* * *} 0.13^{* * *} 0.26^{* * *} 1.00$} \\
\hline M & \multicolumn{10}{|c|}{$0.21^{* * *} 0.17^{* * *} 0.10^{* * *} 0.25^{* * *} 0.13^{* * *} 1.00$} \\
\hline $\mathrm{TM}$ & \multicolumn{10}{|c|}{$0.33^{* * *} 0.20^{* * *} 0.39^{* * *} 0.16^{* * *} 0.20^{* * *} 0.21^{* * *} 1.00$} \\
\hline $\mathrm{BP}$ & \multicolumn{10}{|c|}{$0.28^{* * *} 0.24^{* * *} 0.14^{* * *} 0.19^{* * *} 0.14^{* * *} 0.13^{* * *} 0.14^{* * *} 1.00$} \\
\hline $\mathrm{LO}$ & \multicolumn{10}{|c|}{$0.21^{* * *} 0.19^{* * *} 0.09^{* * *} 0.15^{* * *} 0.11^{* * *} 0.13^{* * *} 0.10^{* * *} 0.47^{* * *} 1.00$} \\
\hline $\mathrm{RM}$ & \multicolumn{10}{|c|}{$0.24^{* * *} 0.19^{* * *} 0.10^{* * *} 0.13^{* * *} 0.11^{* * *} 0.15^{* * *} 0.13^{* * *} 0.34^{* * *} 0.36^{* * *} 1.00$} \\
\hline
\end{tabular}

Notes: Significance levels: $* * * \mathrm{p}<0.01,{ }^{* *} \mathrm{p}<0.05,{ }^{*} \mathrm{p}<0.1$. 


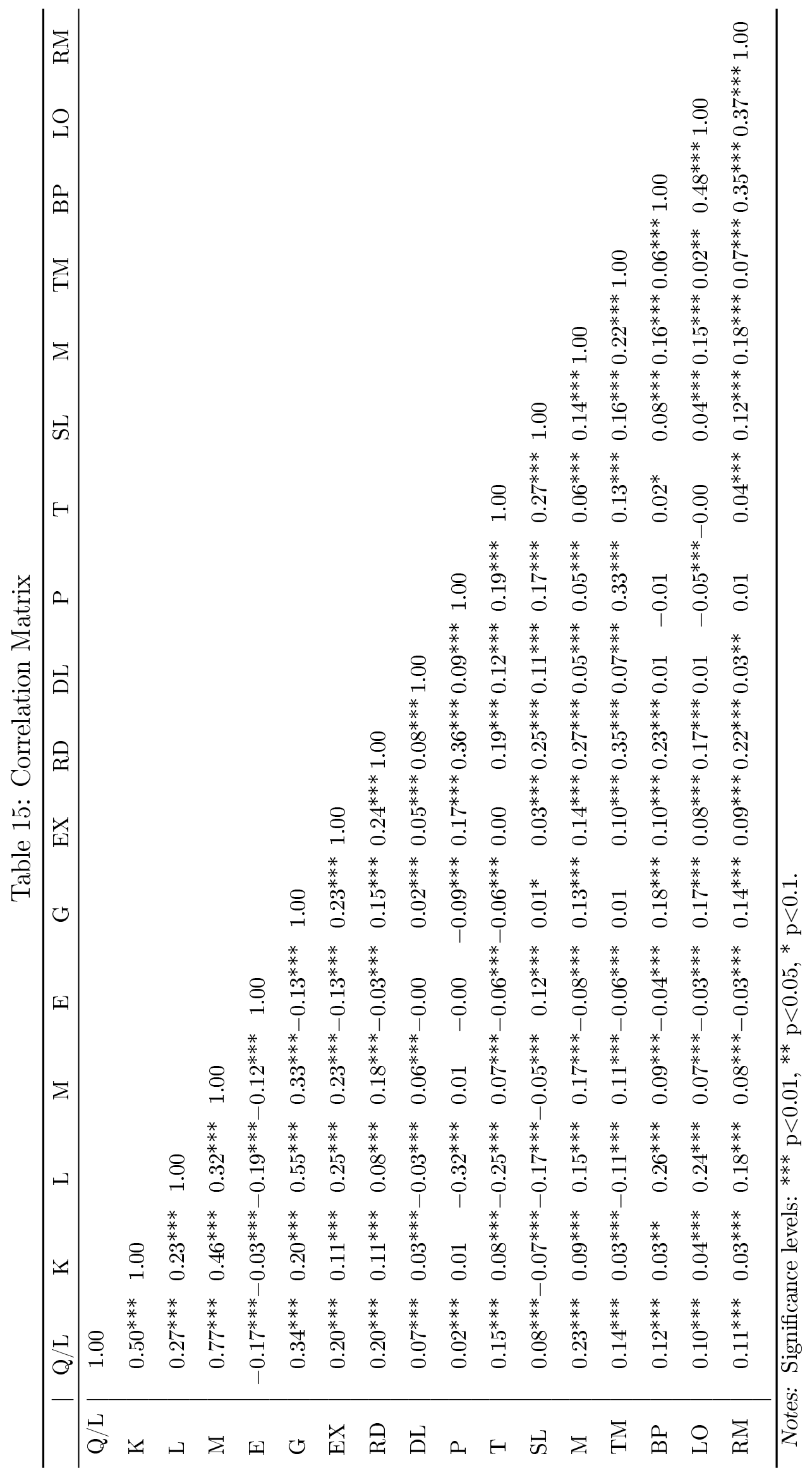




\section{D Testing for Complementarity}

\section{D.1 Overview of variables and hypotheses for seven practices}

\begin{tabular}{|c|c|c|}
\hline$\#$ & Variable & Hypothesis \\
\hline$(1)$ & $\begin{array}{l}x_{1} x_{2}\left(1-x_{3}\right)\left(1-x_{4}\right)\left(1-x_{5}\right)(1- \\
\left.x_{6}\right)\left(1-x_{7}\right)\end{array}$ & $\alpha_{12} \geqslant 0$ \\
\hline$(2)$ & $x_{1} x_{2} x_{3}\left(1-x_{4}\right)\left(1-x_{5}\right)\left(1-x_{6}\right)\left(1-x_{7}\right)$ & $\alpha_{12}+\alpha_{123} \geqslant 0$ \\
\hline$(3)$ & $x_{1} x_{2}\left(1-x_{3}\right) x_{4}\left(1-x_{5}\right)\left(1-x_{6}\right)\left(1-x_{7}\right)$ & $\alpha_{12}+\alpha_{124} \geqslant 0$ \\
\hline$(4)$ & $x_{1} x_{2}\left(1-x_{3}\right)\left(1-x_{4}\right) x_{5}\left(1-x_{6}\right)\left(1-x_{7}\right)$ & $\alpha_{12}+\alpha_{125} \geqslant 0$ \\
\hline$(5)$ & $x_{1} x_{2}\left(1-x_{3}\right)\left(1-x_{4}\right)\left(1-x_{5}\right) x_{6}\left(1-x_{7}\right)$ & $\alpha_{12}+\alpha_{126} \geqslant 0$ \\
\hline$(6)$ & $x_{1} x_{2}\left(1-x_{3}\right)\left(1-x_{4}\right)\left(1-x_{5}\right)\left(1-x_{6}\right) x_{7}$ & $\alpha_{12}+\alpha_{127} \geqslant 0$ \\
\hline$(7)$ & $x_{1} x_{2} x_{3} x_{4}\left(1-x_{5}\right)\left(1-x_{6}\right)\left(1-x_{7}\right)$ & $\alpha_{12}+\alpha_{123}+\alpha_{124}+\alpha_{1234} \geqslant 0$ \\
\hline$(8)$ & $x_{1} x_{2} x_{3}\left(1-x_{4}\right) x_{5}\left(1-x_{6}\right)\left(1-x_{7}\right)$ & $\alpha_{12}+\alpha_{123}+\alpha_{125}+\alpha_{1235} \geqslant 0$ \\
\hline (9) & $x_{1} x_{2} x_{3}\left(1-x_{4}\right)\left(1-x_{5}\right) x_{6}\left(1-x_{7}\right)$ & $\alpha_{12}+\alpha_{123}+\alpha_{126}+\alpha_{1236} \geqslant 0$ \\
\hline$(10)$ & $x_{1} x_{2} x_{3}\left(1-x_{4}\right)\left(1-x_{5}\right)\left(1-x_{6}\right) x_{7}$ & $\alpha_{12}+\alpha_{123}+\alpha_{127}+\alpha_{1237} \geqslant 0$ \\
\hline (11) & $x_{1} x_{2}\left(1-x_{3}\right) x_{4} x_{5}\left(1-x_{6}\right)\left(1-x_{7}\right)$ & $\alpha_{12}+\alpha_{124}+\alpha_{125}+\alpha_{1245} \geqslant 0$ \\
\hline$(12)$ & $x_{1} x_{2}\left(1-x_{3}\right) x_{4}\left(1-x_{5}\right) x_{6}\left(1-x_{7}\right)$ & $\alpha_{12}+\alpha_{124}+\alpha_{126}+\alpha_{1246} \geqslant 0$ \\
\hline (13) & $x_{1} x_{2}\left(1-x_{3}\right) x_{4}\left(1-x_{5}\right)\left(1-x_{6}\right) x_{7}$ & $\alpha_{12}+\alpha_{124}+\alpha_{127}+\alpha_{1247} \geqslant 0$ \\
\hline (14) & $x_{1} x_{2}\left(1-x_{3}\right)\left(1-x_{4}\right) x_{5} x_{6}\left(1-x_{7}\right)$ & $\alpha_{12}+\alpha_{125}+\alpha_{126}+\alpha_{1256} \geqslant 0$ \\
\hline$(15)$ & $x_{1} x_{2}\left(1-x_{3}\right)\left(1-x_{4}\right) x_{5}\left(1-x_{6}\right) x_{7}$ & $\alpha_{12}+\alpha_{125}+\alpha_{127}+\alpha_{1257} \geqslant 0$ \\
\hline$(16)$ & $x_{1} x_{2}\left(1-x_{3}\right)\left(1-x_{4}\right)\left(1-x_{5}\right) x_{6} x_{7}$ & $\alpha_{12}+\alpha_{126}+\alpha_{127}+\alpha_{1267} \geqslant 0$ \\
\hline$(17)$ & $x_{1} x_{2} x_{3} x_{4} x_{5}\left(1-x_{6}\right)\left(1-x_{7}\right)$ & $\alpha_{12}+\alpha_{123}+\alpha_{124}+\alpha_{125}+\alpha_{1234}+\alpha_{1235}+\alpha_{1245}+\alpha_{12345} \geqslant 0$ \\
\hline$(18)$ & $x_{1} x_{2} x_{3} x_{4}\left(1-x_{5}\right) x_{6}\left(1-x_{7}\right)$ & $\alpha_{12}+\alpha_{123}+\alpha_{124}+\alpha_{126}+\alpha_{1234}+\alpha_{1236}+\alpha_{1246}+\alpha_{12346} \geqslant 0$ \\
\hline$(19)$ & $x_{1} x_{2} x_{3} x_{4}\left(1-x_{5}\right)\left(1-x_{6}\right) x_{7}$ & $\alpha_{12}+\alpha_{123}+\alpha_{124}+\alpha_{127}+\alpha_{1234}+\alpha_{1237}+\alpha_{1247}+\alpha_{12347} \geqslant 0$ \\
\hline$(20)$ & $x_{1} x_{2} x_{3}\left(1-x_{4}\right) x_{5} x_{6}\left(1-x_{7}\right)$ & $\alpha_{12}+\alpha_{123}+\alpha_{125}+\alpha_{126}+\alpha_{1235}+\alpha_{1236}+\alpha_{1256}+\alpha_{12356} \geqslant 0$ \\
\hline$(21)$ & $x_{1} x_{2} x_{3}\left(1-x_{4}\right) x_{5}\left(1-x_{6}\right) x_{7}$ & $\alpha_{12}+\alpha_{123}+\alpha_{125}+\alpha_{127}+\alpha_{1235}+\alpha_{1237}+\alpha_{1257}+\alpha_{12357} \geqslant 0$ \\
\hline$(22)$ & $x_{1} x_{2} x_{3}\left(1-x_{4}\right)\left(1-x_{5}\right) x_{6} x_{7}$ & $\alpha_{12}+\alpha_{123}+\alpha_{126}+\alpha_{127}+\alpha_{1236}+\alpha_{1237}+\alpha_{1267}+\alpha_{12367} \geqslant 0$ \\
\hline$(23)$ & $x_{1} x_{2}\left(1-x_{3}\right) x_{4} x_{5} x_{6}\left(1-x_{7}\right)$ & $\alpha_{12}+\alpha_{124}+\alpha_{125}+\alpha_{126}+\alpha_{1245}+\alpha_{1246}+\alpha_{1256}+\alpha_{12456} \geqslant 0$ \\
\hline$(24)$ & $x_{1} x_{2}\left(1-x_{3}\right) x_{4} x_{5}\left(1-x_{6}\right) x_{7}$ & $\alpha_{12}+\alpha_{124}+\alpha_{125}+\alpha_{127}+\alpha_{1245}+\alpha_{1247}+\alpha_{1257}+\alpha_{12457} \geqslant 0$ \\
\hline$(25)$ & $x_{1} x_{2}\left(1-x_{3}\right) x_{4}\left(1-x_{5}\right) x_{6} x_{7}$ & $\alpha_{12}+\alpha_{124}+\alpha_{126}+\alpha_{127}+\alpha_{1246}+\alpha_{1247}+\alpha_{1267}+\alpha_{12467} \geqslant 0$ \\
\hline$(26)$ & $x_{1} x_{2}\left(1-x_{3}\right)\left(1-x_{4}\right) x_{5} x_{6} x_{7}$ & $\alpha_{12}+\alpha_{125}+\alpha_{126}+\alpha_{127}+\alpha_{1256}+\alpha_{1257}+\alpha_{1267}+\alpha_{12567} \geqslant 0$ \\
\hline$(27)$ & $x_{1} x_{2} x_{3} x_{4} x_{5} x_{6}\left(1-x_{7}\right)$ & $\begin{array}{l}\alpha_{12}+\alpha_{123}+\alpha_{124}+\alpha_{125}+\alpha_{126}+\alpha_{1234}+\alpha_{1235}+\alpha_{1236}+ \\
\alpha_{1245}+\alpha_{1246}+\alpha_{1256}+\alpha_{12345}+\alpha_{12346}+\alpha_{12356}+\alpha_{12456}+ \\
\alpha_{123456} \geqslant 0\end{array}$ \\
\hline$(28)$ & $x_{1} x_{2} x_{3} x_{4} x_{5}\left(1-x_{6}\right) x_{7}$ & $\begin{array}{l}\alpha_{12}+\alpha_{123}+\alpha_{124}+\alpha_{125}+\alpha_{127}+\alpha_{1234}+\alpha_{1235}+\alpha_{1237}+ \\
\alpha_{1245}+\alpha_{1247}+\alpha_{1257}+\alpha_{12345}+\alpha_{12347}+\alpha_{12357}+\alpha_{12457}+ \\
\alpha_{123457} \geqslant 0\end{array}$ \\
\hline$(29)$ & $x_{1} x_{2} x_{3} x_{4}\left(1-x_{5}\right) x_{6} x_{7}$ & $\begin{array}{l}\alpha_{12}+\alpha_{123}+\alpha_{124}+\alpha_{126}+\alpha_{127}+\alpha_{1234}+\alpha_{1236}+\alpha_{1237}+ \\
\alpha_{1246}+\alpha_{1247}+\alpha_{1267}+\alpha_{12346}+\alpha_{12347}+\alpha_{12367}+\alpha_{12467}+ \\
\alpha_{123467} \geqslant 0\end{array}$ \\
\hline$(30)$ & $x_{1} x_{2} x_{3}\left(1-x_{4}\right) x_{5} x_{6} x_{7}$ & $\begin{array}{l}\alpha_{12}+\alpha_{123}+\alpha_{125}+\alpha_{126}+\alpha_{127}+\alpha_{1235}+\alpha_{1236}+\alpha_{1237}+ \\
\alpha_{1256}+\alpha_{1257}+\alpha_{1267}+\alpha_{12356}+\alpha_{12357}+\alpha_{12367}+\alpha_{12567}+ \\
\alpha_{123567} \geqslant 0\end{array}$ \\
\hline$(31)$ & $x_{1} x_{2}\left(1-x_{3}\right) x_{4} x_{5} x_{6} x_{7}$ & $\begin{array}{l}\alpha_{12}+\alpha_{124}+\alpha_{125}+\alpha_{126}+\alpha_{127}+\alpha_{1245}+\alpha_{1246}+\alpha_{1247}+ \\
\alpha_{1256}+\alpha_{1257}+\alpha_{1267}+\alpha_{12456}+\alpha_{12457}+\alpha_{12467}+\alpha_{12567}+ \\
\alpha_{124567} \geqslant 0\end{array}$ \\
\hline$(32)$ & $x_{1} x_{2} x_{3} x_{4} x_{5} x_{6} x_{7}$ & $\begin{array}{l}\alpha_{12}+\alpha_{123}+\alpha_{124}+\alpha_{125}+\alpha_{126}+\alpha_{127}+\alpha_{1234}+\alpha_{1235}+ \\
\alpha_{1236}+\alpha_{1237}+\alpha_{1245}+\alpha_{1246}+\alpha_{1247}+\alpha_{1256}+\alpha_{1257}+ \\
\alpha_{1267}+\alpha_{12345}+\alpha_{12346}+\alpha_{12347}+\alpha_{12356}+\alpha_{12357}+\alpha_{12367}+ \\
\alpha_{12456}+\alpha_{12457}+\alpha_{12467}+\alpha_{12567}+\alpha_{123456}+\alpha_{123457}+ \\
\alpha_{123467}+\alpha_{123567}+\alpha_{124567}+\alpha_{1234567} \geqslant 0\end{array}$ \\
\hline
\end{tabular}

Based on Carree et al. (2011). 


\section{E Industry Differences}

Column (1) and (2) provide evidence for the subsample of firms in manufacturing and services, respectively. The following columns (3) to (5) further split manufacturing firms into low-tech (including energy and construction), medium-tech, and high-tech industry according to the OECD/Eurostat classification. Column (6) and column (7) distinguish between firms belonging to knowledge-intensive and low-knowledgeintensive service industries.

Table 16: Effect of Intangibles on Firm-Level Productivity: 1st Stage

\begin{tabular}{lccccccc}
\hline & $(1)$ & $(2)$ & $(3)$ & $(4)$ & $(5)$ & $(6)$ & $(7)$ \\
& Manuf. & Serv. & LT-M & MT-M & HT-M & KI-S & LKI-S \\
\hline Capital & $0.087^{* *}$ & $0.157^{* * *}$ & $0.074^{*}$ & 0.044 & $0.117^{* *}$ & $0.189^{* * *}$ & $0.121^{* *}$ \\
& $(0.035)$ & $(0.041)$ & $(0.040)$ & $(0.043)$ & $(0.052)$ & $(0.054)$ & $(0.060)$ \\
Labour & $-0.011^{* * *}$ & $-0.026^{* * *}$ & 0.002 & $-0.018^{* * *}$ & $-0.019^{*}$ & -0.010 & $-0.046^{* * *}$ \\
& $(0.004)$ & $(0.007)$ & $(0.007)$ & $(0.004)$ & $(0.010)$ & $(0.008)$ & $(0.011)$ \\
Material & $0.476^{* * *}$ & $0.306^{* * *}$ & $0.493^{* * *}$ & $0.459^{* * *}$ & $0.453^{* * *}$ & $0.292^{* * *}$ & $0.307^{* * *}$ \\
& $(0.011)$ & $(0.009)$ & $(0.018)$ & $(0.016)$ & $(0.025)$ & $(0.010)$ & $(0.021)$ \\
East Germany & $-0.117^{* * *}$ & $-0.204^{* * *}$ & $-0.097^{* * *}$ & $-0.146^{* * *}$ & $-0.154^{* * *}$ & $-0.188^{* * *}$ & $-0.232^{* * *}$ \\
& $(0.011)$ & $(0.019)$ & $(0.019)$ & $(0.014)$ & $(0.031)$ & $(0.022)$ & $(0.035)$ \\
Group & $0.118^{* * *}$ & $0.165^{* * *}$ & $0.162^{* * *}$ & $0.108^{* * *}$ & $0.067^{*}$ & $0.148^{* * *}$ & $0.172^{* * *}$ \\
& $(0.014)$ & $(0.024)$ & $(0.027)$ & $(0.015)$ & $(0.035)$ & $(0.030)$ & $(0.038)$ \\
Export & $0.150^{* * *}$ & $0.098^{* *}$ & $0.203^{* * *}$ & $0.125^{* * *}$ & $0.194^{* * *}$ & 0.083 & 0.117 \\
& $(0.021)$ & $(0.047)$ & $(0.046)$ & $(0.025)$ & $(0.054)$ & $(0.058)$ & $(0.090)$ \\
\hline W_Time & 0.063 & 0.443 & 0.308 & 0.010 & 0.001 & 0.090 & 0.382 \\
W_Industry & 0.000 & 0.000 & 0.178 & 0.000 & 0.000 & 0.000 & 0.000 \\
Adjusted $R^{2}$ & 0.755 & 0.667 & 0.771 & 0.783 & 0.680 & 0.696 & 0.553 \\
Observations & 6,622 & 4,400 & 2,481 & 3,198 & 943 & 2,941 & 1,459 \\
\hline
\end{tabular}

Notes: Significance levels: ${ }^{* * *} \mathrm{p}<0.01,{ }^{* *} \mathrm{p}<0.05,{ }^{*} \mathrm{p}<0.1$. Standard errors in parentheses. Estimation method: Olley and Pakes (1996). LTM, MTM, and HTM denote low-tech manufacturing (including energy and construction), medium-tech manufacturing, and high-tech manufacturing. KIS denotes knowledge-intensive and LKIS low-knowledge-intensive services. 
Table 17: Effect of Intangibles on Firm-Level Productivity: 2nd Stage

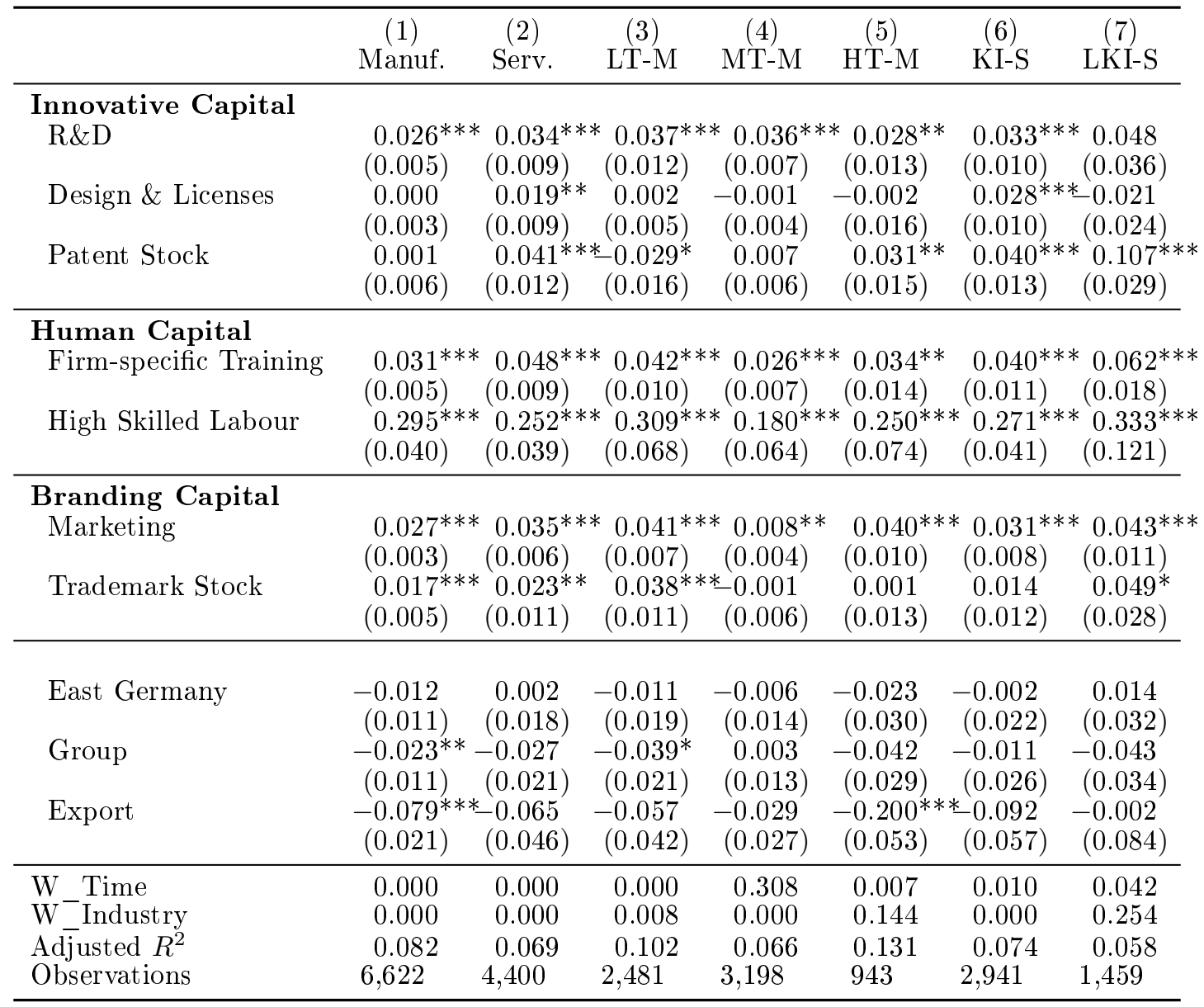

Notes: Significance levels: $* * * \mathrm{p}<0.01,{ }^{* *} \mathrm{p}<0.05,{ }^{*} \mathrm{p}<0.1$. Standard errors in parentheses. Estimation method: Olley and Pakes (1996). The number of observations refers to the first stage regression. Regression additionally includes six dummies indicating R\&D, Design \& Licenses, Firm-specific Training, Marketing, and Trademark Stock is zero. LTM, MTM, and HTM denote low-tech manufacturing (including energy and construction), medium-tech manufacturing, and high-tech manufacturing. KIS denotes knowledge-intensive and LKIS lowknowledge-intensive services. 